
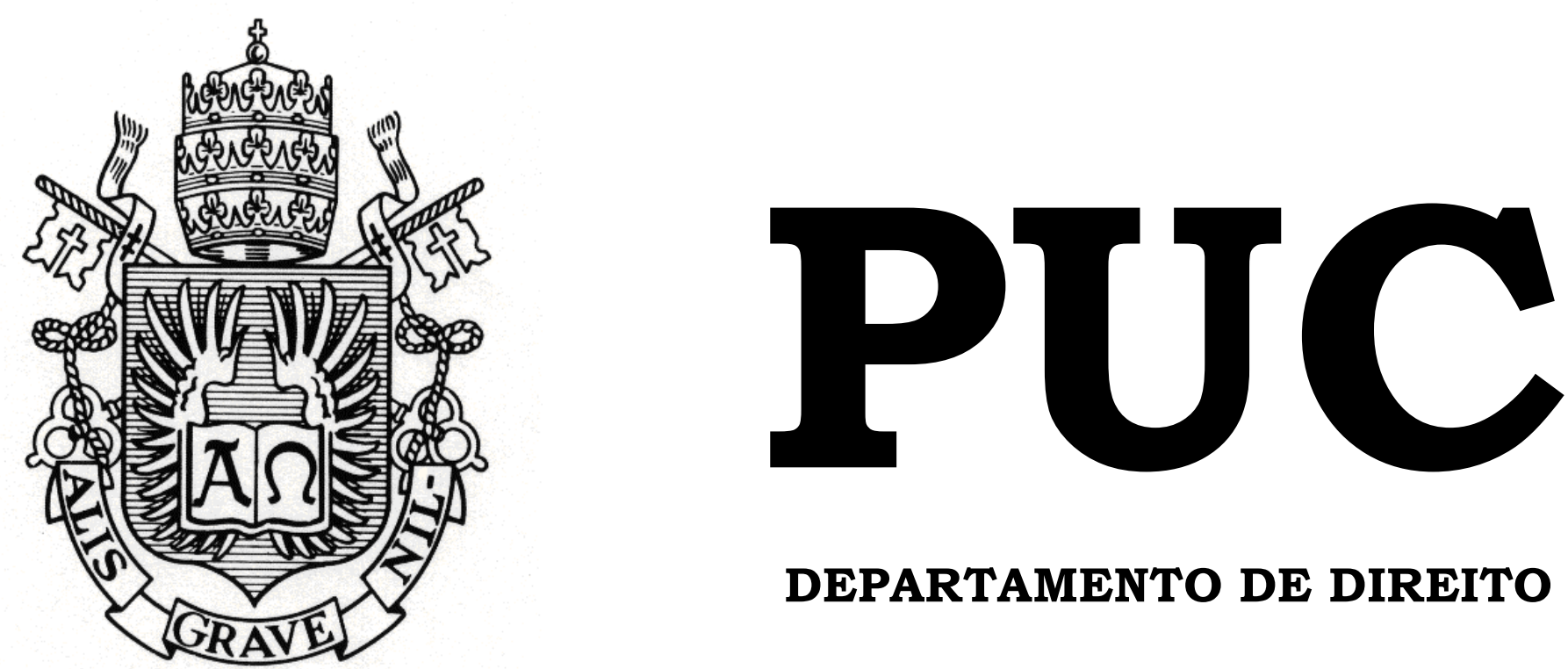

DEPARTAMENTO DE DIREITO

\title{
A NECESSIDADE DO EXAURIMENTO DA ESFERA ADMINISTRATIVA PARA REPRESENTAÇÃO FISCAL PARA FINS PENAIS
}

por

JOSEF AZULAY NETO

ORIENTADOR: DIOGO RUDGE MALAN

2010.2

PONTIFÍCIA UNIVERSIDADE CATÓLICA DO RIO DE JANEIRO

RUA MARQUÊS DE SÃO VICENTE, 225 - CEP 22453-900

RIO DE JANEIRO - BRASIL 


\title{
A NECESSIDADE DO EXAURIMENTO DA ESFERA ADMINISTRATIVA PARA A REPRESENTAÇÃO FISCAL PARA FINS PENAIS
}

\author{
por \\ JOSEF AZULAY NETO
}

Monografia

apresentada

ao

Departamento de Direito da Pontifícia Universidade Católica do Rio de Janeiro (PUC-Rio) para a obtenção do Título de Bacharel em Direito.

Orientador: Diogo Rudge Malan 
Dedico esta monografia aos meus pais, e minhas irmãs pelo exemplo de vida $e$ estímulo permanente na busca de meu aprendizado. 


\section{A GR A DE CIMENTOS}

Às minhas irmãs Julie e Rosane, pelos momentos de felicidade e alegria que sempre me proporcionam, e pela compreensão e ajuda que sempre me fornecem.

Ao meu professor orientador Diogo Malan, que não só esteve atento as

minhas dúvidas ao longo deste trabalho e cujo apoio e dedicação foram fundamentais, como também pelas dicas e conselhos, que contribuíram para ampliar e diversificar minha visão do Direito, transformando esse projeto em uma experiência enriquecedora que certamente me fez crescer como pessoa e futuro operador do Direito. 


\section{R ES U M O}

Este trabalho analisa principalmente a necessidade do esgotamento da esfera administrativa para a possibilidade de representação fiscal para fins penais. De início, foi abordada a polêmica acerca da (in)dependência das esferas administrativo-fiscal e penal, através de um olhar sobre a evolução histórica dos dispositivos, as garantias constitucionais, e todo o debate acerca da natureza jurídica da representação fiscal. Em seguida, foi comentada a solução encontrada pelo Judiciário - STF - para solucionar a questão. Por fim, foram levantados pontos que até hoje se encontram indefinidos, acoplados a uma visão sobre a máxima da proporcionalidade, para entender e fundamentar o presente trabalho.

Palavras-Chave: representação fiscal; (in)dependência das esferas; crime material; proporcionalidade. 
"Tenho para mim que sou essencialmente um leitor. Como sabem, eu me aventurei na escrita; mas acho que o que li é muito mais importante que o que escrevi. Pois a pessoa lê o que gosta - porém não escreve o que gostaria de escrever, e sim o que é capaz de escrever."

Jorge Luis Borges

"Esse Ofício do Verso" 


\section{S U M Á R I O}

1 - INTRODUÇÃO

08

2 - A POLÊMICA ACERCA DA (IN)DEPENDÊNCIA ENTRE AS INSTÂNCIAS ADMINISTRATIVO-FISCAL E PENAL 10

2.1 - Breve evolução histórica 10

2.2 - Garantias Constitucionais 14

2.3 - Natureza jurídica do Artigo 83 da Lei 9430/96 17

2.3.1 - Condição de Procedibilidade 18

2.3.2 - Questão Prejudicial Heterogênea 22

2.3.3 - Condição Objetiva de Punibilidade 27

2.3.4 - Elemento Normativo do Tipo 29

3 - A ATUAL POSIÇÃO DO STF ACERCA DA MATÉRIA 35

3.1 - Análise do HC 81.611 - DF 36

3.1.1 - O caso 36

3.1.2 - A Natureza de crime material 37

3.1.3 - O Enquadramento da decisão de lançamento definitivo do tributo dentro da estrutura do delito $\quad 40$

3.1.4 - Extinção da punibilidade pelo pagamento 44

3.1.5 - Prescrição da pretensão punitiva 46

3.2 - Súmula Vinculante № 24 - STF 49

3.2.1 - Análise dos precedentes $\quad 49$

3.2.2 - Exposições de Motivos 55

4 - ASPECTOS ATUAIS ACERCA DA MATÉRIA PÓS HC 81.611- DF 58

4.1 - Prescrição 58

4.2 - Aplicabilidade da Súmula a outros casos $\quad 64$

4.2.1 - Artigo 20 da Lei 8137/90 64

4.2.2 - Crime de Descaminho 66

4.2.3 - Crime de Apropriação em débita previdenciária 69

$\begin{array}{ll}4.3 \text { - A Máxima da proporcionalidade } & 73\end{array}$

4.3.1 - Colisão entre Direitos Fundamentais $\quad 74$

4.3.2 - A estrutura da ponderação - conjunto da proporcionalidade $\quad 79$

4.4 - Perspectivas de Reforma Legislativa 85

5 - CONCLUSÃO 94

6 - BIBLIOGRAFIA 97 


\section{LISTA DE SIGLAS}

\begin{tabular}{ll} 
ADIN & Ação Direta de Inconstitucionalidade \\
CF & Constituição Federal \\
CP & Código Penal \\
CPP & Código de Processo Penal \\
CTN & Código Tributário Nacional \\
HC & Habeas Corpus \\
IBCCRIM & Instituto Brasileiro de Ciências Criminais \\
INSS & Instituto Nacional de Seguridade Social \\
MP & Ministério Público \\
MPF & Ministério Público Federal \\
PGJ & Procurador Geral de Justiça \\
RESP & Recurso Especial \\
RFB & Receita Federal do Brasil \\
RFFP & Representação Fiscal para Fins Penais \\
RHC & Recurso em Habeas Corpus \\
SEF & Secretário de Estado de Fazenda \\
SSP & Secretário da Segurança Pública \\
STF & Supremo Tribunal Federal \\
STJ & Superior Tribunal de Justiça \\
\hline
\end{tabular}




\section{1 - INTRODUÇÃO}

O presente Trabalho Monográfico visa abordar a questão da necessidade do exaurimento da esfera administrativa para a possibilidade da representação fiscal para fins penais.

Este tema vem sendo discutido há tempos, e a primeira questão a ser levantada pelos hermeneutas do Direito, foi a polêmica acerca da (in)dependência das esferas adminsitrativo-fiscal e penal, questão esta que será analisada em nosso primeiro Capítulo.

Adiante, no Segundo Capítulo, será analisado como e quais foram os fundamentos utilizados por nossos Tribunais - mais precisamente o Supremo Tribunal Federal - para resolver este deslinde.

Ocorre que a atual posição do Excelso Pretório, ao decidir sobre o esgotamento da esfera fiscal para adentrar a esfera penal, deixou em aberto algumas questões de extrema relevância, sem precisar ao certo como proceder em relação às mesmas. E são essas questões, aliadas a uma visão de proporcionalidade, que serão abordadas em nosso terceiro Capítulo, juntamente com as perspectivas de reforma legislativa a cerca da matéria.

Diante dos tópicos e discussões acima mencionados e que serão examinados ao longo deste trabalho, a melhor maneira de abordar o tema será através de um estudo analítico e comparativo de todas as correntes doutrinarias acerca da matéria, bem como a evolução e adequação jurisprudencial que foi se construindo nesses longos anos de discussão.

E assim, convencido da relevância do tema, sobretudo, em razão das mais diversas correntes doutrinárias não terem alcançado unanimidade no entendimento, e de o atual posicionamento jurisprudencial acerca da matéria 
não ter esgotado o tema, deixando terrenos lacunosos, é que baseio meu estudo. O principal objetivo deste é tentar aclarar as inúmeras incongruências e entendimentos antagônicos, acreditando-se que, dessa maneira, o mesmo possa contribuir para uma aplicação mais contemporânea do Direito, que deve acompanhar as transformações comportamentais da sociedade em qualquer tempo e época, coadunando-se a moral e a realidade vigente e também consolidar-se como instrumento eficaz nas mãos de seus operadores. 


\section{2 - A POLÊMICA ACERCA DA (IN)DEPENDÊNCIA ENTRE AS INSTÂNCIAS ADMINISTRATIVO-FISCAL E PENAL}

Por muitos anos, discutiu-se sobre a independência, ou não, das esferas administrativo-fiscal e penal. A discussão de tal celeuma é de assaz importância para entendermos o deslinde da representação fiscal para fins penais, uma vez que a mesma abarcava diversas correntes que defendiam inúmeros posicionamentos distintos, baseados em conceitos próprios e muitos diferentes.

Contudo, antes de adentrarmos a análise de cada um, na espécie, mister se faz abordar uma breve evolução histórica do instituto da representação fiscal para fins penais, em nossa legislação.

\section{1 - Breve evolução histórica}

Os crimes que atualmente recebem a nomenclatura de crimes contra ordem tributária, elencados na Lei 8137/90, eram definidos inicialmente na Lei 4729/65, como crimes de sonegação fiscal.

Todavia, foi o parágrafo $3^{\circ}$ do artigo 11 da Lei 4357/64 o primeiro dispositivo a prever a representação fiscal, proibindo os Agentes Fazendários de remeterem material fiscal á Procuradoria da República para fins de ação penal, antes de encerrado o procedimento administrativo que concluir sobre a existência ou não da obrigação tributária. ${ }^{1} 2$

\footnotetext{
${ }^{1} \S 3^{\circ}$ Nos casos previstos neste artigo, a ação penal será iniciada por meio de representação da Procuradoria da República, à qual a autoridade de julgadora de primeira instância é obrigada a encaminhar as peças principais do feito, destinadas a comprovar a decisão final condenatória proferida na esfera administrativa.
} 
Essa espera quanto à decisão final condenatória na esfera administrativa, transitada em julgado, era entendida por muitos autores como uma clara questão de condição procedibilidade, condicionando a esfera penal ao término da esfera fiscal. E como leciona Mirabete: “As questões de procedibilidade são as que condicionam o exercício da ação penal, têm caráter processual e se atêm somente à admissibilidade da persecução penal." 3

Posteriormente, o Decreto 982 de 12 de novembro de 1993 determinava, em seus artigos $1^{\circ}$ e $3^{\circ}$, parágrafo $2^{\circ}$, o imediato envio de representação fiscal para fins penais ao Ministério Público, pelas autoridades fiscais, tão logo fosse expedido o Auto de Infração ou a notificação fiscal de lançamento do débito, como demonstrado abaixo:

"Art.1 ${ }^{\circ}$ Os Auditores-Fiscais do Tesouro Nacional, no exercício das atribuições de fiscalização, de lançamento ou de cobrança de tributos e contribuições devidos à Fazenda Nacional, representarão, perante o Secretário da Receita Federal, com cópia para o titular da unidade administrativa em que tenham exercício e para o Superintendente Regional da Receita Federal, sempre que apurarem ilícitos que entendam configurar:

$(\ldots)$

$\S 1^{\circ}$ Quando o crime for praticado ou constatado no curso de processo administrativofiscal, de atividade de cobrança, diligência ou outro procedimento administrativo, o servidor que dele tomar conhecimento comunicará o fato, imediatamente, ao chefe da respectiva unidade administrativa, que formalizará a representação criminal.

$\S 2^{\circ}$ Se a falta se der na fase de apreciação do recurso administrativo voluntário, o Conselheiro relator, ou o Conselheiro designado para redigir o voto vencedor, registrará o fato, destacadamente, em seu voto, cabendo ao Procurador da Fazenda Nacional junto à Câmara do Conselho de Contribuintes formalizar, imediatamente, a representação de que trata o parágrafo anterior."

\footnotetext{
${ }^{2}$ David Teixeira de Azevedo criticava o dispositivo em análise, por possuir clara falta de técnica, pois notoriamente a pretensão penal é deduzida por intermédio de denúncia, a ser oferecida pelo próprio representante da Procuradoria, não fazendo sentido ela representar para si mesmo. (AZEVEDO, David Teixeira de. A representação penal e os crimes tributários: reflexão sobre o artigo 83 da Lei 9430/96. Revista dos Tribunais, São Paulo, v.86, n 739, p. 475-486, maio de 1997, p 476)

${ }^{3}$ MIRABETE, Julio Fabbrini. Processo Penal/ Julio Fabbrini Mirabete. - 13. Ed. rev. e atual. até dezembro de 2001 - São Paulo: Atlas, 2002, p 108.
} 
Enfatizava, o $\S 2^{\circ}$ do artigo $3^{\circ}$ do mesmo diploma legal, o oferecimento imediato da denúncia:

"\$2 A representação será instruída com cópias de todos os autos de infração ou cópias das notificações de lançamento expedidas, seguidas dos demais termos e atos lavrados, diligências e perícias realizadas, devidamente indexados na peça básica, por referência expressa aos números das folhas dos autos, com indicação clara das circunstâncias e provas razoáveis ao convencimento do Ministério Público, de modo a viabilizar o oferecimento imediato da denúncia."

Após a leitura dos trechos desse diploma, fácil concluir que o presente Decreto aparentava ter modificado o primeiro entendimento sobre a necessidade de se aguardar a decisão final condenatória, caracterizando assim, a independência das instâncias.

Isso porque a qualquer momento que se apurasse o ilícito, o Ministério Público deveria ser comunicado, para de plano iniciar a ação penal, seja no início do procedimento, seja no momento do julgamento, tanto na primeira instância - Delegacia de Receita e Julgamento - quanto na segunda instância Conselho dos Contribuintes.

Passados poucos anos, foi editada Lei sobre a legislação tributária federal, Lei 9430/96, que previa em seu artigo 83, a necessidade, novamente, de aguardar-se a decisão final da esfera administrativa, para haver a representação fiscal para fins penais. ${ }^{4}$

Esse dispositivo é o que vigora atualmente, e quando introduzido em nosso ordenamento, tudo indicava que o mesmo serviria para elucidar a questão da representação fiscal, por haver uma redação clara, e compreensível.

\footnotetext{
4 Art. 83. A representação fiscal para fins fiscais relativa aos crimes contra a ordem tributária definidos nos arts. $1^{\circ}$ e $2^{\circ}$ da Lei 8137, de 27/12/1990, será encaminhada ao Ministério Público após proferida a decisão final, na esfera administrativa, sobre a existência fiscal do crédito tributário correspondente.
} 
Atualmente, a disciplina procedimental da representação fiscal para fins penais está regulamentada, principalmente, na Portaria n ${ }^{\circ}$ 665/08 da Receita Federal, que, bem como as demais Portarias que lhe precederam, foi resultante da prática dos julgamentos sobre a matéria em nossos Tribunais.

No artigo $1^{\mathrm{o}}$ da Portaria supra ${ }^{5}$, evidencia-se claro, que os AuditoresFiscais apenas devem formalizar - e não remeter diretamente ao Ministério Público - a representação fiscal, perante o Delegado da Receita Federal, juntando a documentação necessária, caso identificassem situações que, em tese, configurariam crime contra a ordem tributária.

De igual forma, o artigo $3^{\circ}$ do mesmo diploma legal ${ }^{6}$ deixa muito claro que, mesmo formalizada a representação, esta deverá permanecer no âmbito da unidade de controle, até que o crédito tributário se torne definitivo. Dessa maneira, estar-se-ia comprovando que é necessário aguardar o desfecho na esfera administrativa para iniciar a representação fiscal.

Por outro turno, no âmbito estadual, mais precisamente no Estado do Rio de Janeiro, a disciplina encontra-se regulamentada pela Resolução Conjunta SEF/SSP/PGJ nº 01/1997. Da mesma forma que acontece no âmbito federal, os fiscais de renda devem representar ao Secretário Estadual da Fazenda, quando no exercício de suas funções apurarem a existência de fatos ou atos que caracterizem a prática de ilícitos de natureza tributária, e depois este encaminhará a representação ao Superintendente Estadual de Fiscalização.

\footnotetext{
${ }^{5}$ Art. $1^{\circ}$ Os Auditores-Fiscais da Receita Federal do Brasil deverão formalizar representação fiscal para fins penais, perante o Delegado ou Inspetor-Chefe da Receita Federal do Brasil responsável pelo controle do processo administrativo-fiscal, sempre que no exercício de suas atribuições identificarem situações que, em tese, configurem crime relacionado com as atividades da Secretaria da Receita Federal do Brasil (RFB).

${ }^{6}$ Art. $3^{\circ}$ A representação fiscal para fins penais relativa aos crimes contra a Ordem Tributária definidos nos arts. $1^{\circ}$ e $2^{\circ}$ da Lei $\mathrm{n}^{\circ} 8.137$, de 27 de dezembro de 1990, será formalizada e protocolizada em até 10 (dez) dias contados da data da constituição do crédito tributário, devendo permanecer no âmbito da unidade de controle até que o referido crédito se torne definitivo na esfera administrativa, respeitado o prazo para cobrança amigável.
} 
Ocorre que a leitura da Resolução - principalmente o art. $2^{\circ}$, I, art. $4^{\circ}$, e $5^{\circ}$ 7_ da margem à interpretação de que a representação já poderia ser encaminhada ao Ministério Público para que este, inclusive, participe das investigações, o que não estaria em consonância com o atual procedimento regulatório federal - qual seja, aguardar o lançamento definitivo.

Essa não consonância ocorre, pois a Resolução Conjunta Estadual é bem anterior à atual Portaria da Receita Federal, e infelizmente, em função desta interpretação equivocada, os órgãos estaduais podem utilizá-la de maneira errônea, quando remetem o material ao MP, possibilitando o início de uma persecução penal pré-matura.

Dessa maneira, o resultado pretendido e, por muito tempo debatido, não era alcançado, continuando a doutrina a discutir sobre a natureza jurídica do instituto, bem como a questão da (in)dependência das esferas.

\section{2 - Garantias Constitucionais}

Se formos recorrer a Constituição Federal para tentar solucionar essa questão, poderemos esbarrar em princípios fundamentais que se contrapõem, pois ambas as posições estão amparadas pelo Art. $5^{\circ}$.

\footnotetext{
7 “Art. 2. ${ }^{\circ}$ Caberá ao Superintendente Estadual de Fiscalização: I - remeter o processo administrativotributário ao Promotor de Justiça especialmente designado na forma do artigo $4^{\circ}$ desta Resolução Conjunta, mediante encaminhamento nos próprios autos;"

"Art. 4. ${ }^{\circ}$ O Promotor de Justiça com atribuição para atuar nos processo administrativo-tributários referidos nesta Resolução Conjunta, bem como nas peças de informação e inquéritos policiais que versem sobre crimes contra a ordem tributária e conexos, poderá trabalhar junto à Secretaria de Estado de Fazenda, sempre que julgar necessário ao bom andamento das investigações.

“Art. 5. Ao Promotor de Justiça mencionado no artigo anterior incumbirá, em 15 (quinze) dias: I oferecer denúncia, se os elementos formadores de sua opinio delicti já estiverem presentes;"
} 
A afirmativa supra se dá pela leitura dos incisos XXXV, e LV. Enquanto o primeiro aduz que "a Lei não excluirá da apreciação do Poder Judiciário lesão ou ameaça a direito", o segundo dispõe que "aos litigantes, em processo judicial ou administrativo, e aos acusados em geral são assegurados o contraditório e a ampla defesa, com meios e recursos a ela inerentes."

Ora, se a própria Lei Maior prevê as garantias do contraditório e da ampla defesa na esfera administrativa - no caso em tela, no procedimento administrativo fiscal - como poderá ter início uma persecução penal em face de um contribuinte que sequer se sabe ser ele devedor de um tributo, que dirá, o montante do débito? ${ }^{89}$

Não é outro o entendimento do renomado jurista, Hugo de Brito Machado $^{10}$, sobre a garantia da ampla defesa, e do contraditório, senão vejamos:

"A exigência de prévio exaurimento da via administrativa, para que validamente possa ser proposta a ação penal, nos crimes contra ordem tributária, é indiscutivelmente uma forma de fazer efetivas as garantias constitucionais do devido processo legal e da ampla defesa, induvidoso como é o direito do contribuinte ao regular e prévio procedimento administrativo de acertamento. No Direito brasileiro, a necessidade de prévia decisão da autoridade administrativa, no crime de supressão ou redução de tributo, é muito mais do que uma questão de Direito Penal ou Processual. É uma questão de Direito Constitucional. Admitir-se a denúncia criminal antes da decisão definitiva da autoridade da Administração, é forma clara de negação da supremacia constitucional."

E seguem outros hermeneutas do direito no mesmo sentido, no caso Suzane de Farias Machado Moraes ${ }^{11}$ :

\footnotetext{
${ }^{8}$ Esse questionamento ocorre, pois o contribuinte quando interpõe impugnação, ou recurso voluntário, perante aos Agentes Fazendários, está querendo provar que não deve aquele tributo, ou que deve menos do que lhe foi lançado, tornado-se impossível falar de supressão ou redução de tributos como dito no artigo $1^{\circ}$ da Lei 8137/90.

${ }^{9}$ Nesse sentido, VIDGAL, Edson Carvalho. Fluxo de Cadeia ou de caixa - O exaurimento da instância administrativo-fiscal como condição de procedibilidade para a ação penal. Revista dos Tribunais, n764, p. 453-458, jun 1999, p. 457.

${ }^{10}$ MACHADO, Hugo de Brito. Prévio esgotamento da via administrativa e ação penal nos crimes contra a ordem tributária. Revista Brasileira de Ciências Criminais, São Paulo, no 15, p. 231-239, jul/set 1996, p.237.
} 
“Aceitar a instrução do processo penal, antes de concluído o procedimento administrativo, é negar a garantia da ampla defesa ao contribuinte. Admitir a denúncia antes do processo administrativo, pode até atender ao Estado, que estará arrecadando, mas o direito às garantias constitucionais do contribuinte estará sendo cerceado. E não se pode aceitar o argumento de que sendo indevido o tributo ao final restará comprovado e a ação penal ficará prejudicada. Não é possível admitir-se que alguém seja submetido ao constrangimento de um processo penal, antes mesmo de saber se cometeu o delito a ele imputado."

Assim, por esse entendimento, não restaria dúvida de que remeter material fiscal, ao Ministério Público, sem o esgotamento da via administrativa, iniciando uma persecutio criminis, seria uma total violação a essas garantias.

Em contrapartida, há quem se posicione de forma completamente oposta, alegando que o dispositivo em exame seria inconstitucional, por estar havendo um obste ao Poder Judiciário, único competente para apreciar a ameaça ou lesão a direito.

\section{Entendem Francisco Bissoli Filho e Gustavo Wiggers ${ }^{12}$, que, por esse} princípio, o legislador constituinte buscou garantir o livre acesso de qualquer pessoa ao Poder Judiciário, sem aguardar que uma prévia instância administrativa imponha sua vontade perante a Lei, como antes era garantido pela Constituição Federal de $1967 .{ }^{13}$

E concluem os autores que a função do Poder Judiciário é a jurisdição, e retirar-lhe esta, entregando-a a qualquer outro órgão da administração pública, seria ferir mortalmente o principio da inafastabilidade desse órgão.

\footnotetext{
${ }^{11}$ MORAES, Suzane de Farias Machado. Prévio esgotamento da via administrativa como condição para a ação penal nos crimes contra a ordem tributária. Revista Dialética de Direito Tributário. São Paulo, no 97, p. 85-95, out. 2003. p. 89.

${ }^{12}$ WIGGERS, Gustavo \& BISSOLI FILHO, Francisco. A inconstitucionalidade do encerramento do processo administrativo fiscal como condição de procedibilidade para o exercício da ação penal. Boletim IBCCrim, São Paulo, v.8, n.93, p. 13-15, ago. 2000. p.13

${ }^{13}$ Art. $153, \S 4^{\circ}$ : A lei não poderá excluir da apreciação do Poder Judiciário qualquer lesão de direito individual. $\mathrm{O}$ ingresso em juízo poderá ser condicionado a que se exauram previamente as vias administrativas, desde que não exigida garantia de instância, nem ultrapassado o prazo de cento e oitenta dias para a decisão sobre o pedido.
} 
E da mesma maneira, condicionar a atuação do Judiciário à decisão administrativo-tributária emanada do Executivo, significaria quebrar a independência daquele Poder, pois, diante de uma denúncia do Ministério Púbico, o Magistrado não poderia instaurar o processo penal se a matéria estivesse sob análise em processo administrativo, violando, também, a garantia da separação dos poderes. ${ }^{14}$

Ocorre que a doutrina majoritária não entende dessa maneira, aduzindo como frágeis os argumentos da parte minoritária, pois não abarcam as garantias do contraditório e da ampla defesa, permitindo que qualquer cidadão tenha o direito de se defender, por todos os meios cabíveis, de qualquer acusação que venha a sofrer. E no caso em tela, não haveria como prosperar uma persecução penal, sem antes dar ao contribuinte a chance de impugnar os valores lançados pelos Órgãos Fazendários. ${ }^{15}$

Ultrapassada a questão quanto às garantias constitucionais, podemos adentrar uma melhor analise do Artigo 83 da Lei 9.430/96, atualmente em vigor, para debatermos sobre a discussão doutrinária quanto a sua natureza jurídica.

\section{3- Natureza jurídica do Artigo 83 da Lei 9430/96}

$\mathrm{Na}$ discussão acerca da apuração contra crimes de ordem tributária, mereciam destaque duas posições. A primeira, preponderantemente jurisprudencial, no sentido de que a instauração da ação penal, independia da conclusão do procedimento administrativo fiscal, já que as instâncias eram independentes; e a segunda, predominantemente doutrinária, no sentido de que

\footnotetext{
${ }^{14}$ WIGGERS, Gustavo \& BISSOLI FILHO, Francisco. Op. cit. 14

${ }^{15}$ Esta questão será melhor explanada no tópico 4.3
} 
a conclusão do procedimento fiscal impedira a ação penal, por não se caracterizar ainda ofensa ao bem juridicamente tutelado, demonstrando a dependência das instâncias.

Assim, serão demonstradas, a seguir, as diversas correntes doutrinarias que perfizeram o caminho para tentar demonstrar a dependência das instâncias, através da natureza jurídica da representação fiscal para fins penais, quais sejam: condição de procedibilidade; condição prejudicial heterogênea; condição objetiva de punibilidade; e o tributo devido como elemento normativo do tipo.

\subsection{1 - Condição de Procedibilidade}

A primeira corrente que analisaremos para definir a natureza jurídica do instituto da representação fiscal é a que a doutrina chama de condição de procedibilidade.

E como já exposto anteriormente, a procedibilidade é entendida como condição do exercício da ação penal, tendo caráter processual e se atendo somente a admissibilidade da persecução penal. ${ }^{16}$

Indo além, no sábio magistério de Hugo de Brito Machado, define-se que a condição de procedibilidade concerne exclusivamente ao processo, enquanto a questão prejudicial diz respeito ao direito material. ${ }^{17}$

Dito isto, David Teixeira de Azevedo entendia que o artigo 83 da Lei 9430/96 veio trazer expressa condição de procedibilidade, tendo em vista que se não poderia haver representação era porque, para os crimes definidos nos artigos $1^{\circ}$ e $2^{\circ}$ da Lei $8137 / 90$, a ação penal ficava condicionada a providência

\footnotetext{
${ }^{16}$ MIRABETE, Julio Fabbrini. Op. cit. p 108

${ }^{17}$ MACHADO, Hugo de Brito. Op. cit. p 232
} 
da parte ofendida na manifestação do desejo de processar o autor da suposta infração penal. ${ }^{18}$

Em outras palavras, o MP só poderia deflagrar a ação penal após a necessária representação dos Agentes Fazendários, tornando a ação penal pública condicionada. ${ }^{19} 20$

Contudo, houve quem discordasse desse condicionamento, e, dessa forma, se insurgiu contra o dispositivo do artigo 83, argumentando que não era condição de procedibilidade, e que não poderia impedir a atuação do Ministério Público.

Nesse sentido, o Procurador Geral da República arguiu ADIn 1.571-1-DF, para suspender os efeitos desse diploma legal. Alegou que a representação estaria violando o artigo 129, I, VI, e VII da Constituição Federal, por ser a ação penal pública privativa do Ministério Público, bem como o entendimento cristalizado na Súmula 608 do STF, que dizia ser ação penal pública incondicionada nos crimes contra a ordem tributária.

Em sede liminar, o Ministro Néri da Silveira, havia decido pela improcedência do pedido, entendendo que não era condição de procedibilidade para instaurar a ação penal, e que o dispositivo não impediria a ação do Ministério Público, pois poderia o mesmo órgão, pelos mais diversificados meios de sua ação ter conhecimento de atos criminosos na ordem tributária. Não ficaria, o MP, impedido de agir, desde logo, utilizando-se de outros meios de prova a que tivesse acesso, como demonstrado abaixo:

\footnotetext{
${ }^{18}$ AZEVEDO, David Teixeira de. Op. cit. p 477

${ }^{19}$ Também encontramos outros exemplos de procedibilidade no processo penal nos casos de ação penal publica condicionada, por representação do ofendido e por requisição do Ministério da Justiça, nos quais, sem a representação do ofendido, e nem a requisição daquele Ministério, será impossível o MP deflagrar a ação penal.

${ }^{20}$ Nessa linha, TORON, Alberto Zacharias; \& TORIHARA, Edson Junji. Crimes tributários e condição de procedibilidade. Boletim IBCCRIM. São Paulo, nº 51, p.8, fev.1997. p. 08
} 
“Ação direta de inconstitucionalidade. 2. Lei n 9430, de 27.12.1996, art. 83. 3. Argüição de inconstitucionalidade da norma impugnada por ofensa ao art. 129, I, da Constituição, ao condicionar a notitia criminis contra a ordem tributária "a decisão final, na esfera administrativa, sobre a exigência fiscal do crédito tributário", do que resultaria limitar o exercício da função institucional do Ministério Público para promover a ação penal pública pela prática de crimes contra a ordem tributária. 4 . Lei $n^{\circ} 8137 / 1990$, arts. $1^{\circ}$ e $2^{\circ}$. 5. Dispondo o art. 83, da Lei $n^{\circ} 9430 / 1996$, sobre a representação fiscal, há de ser compreendido nos limites da competência do Poder Executivo, o que significa dizer, no caso, rege atos da administração fazendária, prevendo o momento em que as autoridades competentes dessa área da Administração Federal deverão encaminhar ao Ministério Público Federal os expedientes contendo notitia criminis, acerca de delitos contra a ordem tributária, previstos nos arts. $1^{\circ}$ e $2^{\circ}$, da Lei $n^{\circ} 8137 / 1990.6$. Não cabe entender que a norma do art. 83, da Lei $n^{\circ}$ 9430/1996, coarcte a ação do Ministério Público Federal, tal como prevista no art. 129, I, da Constituição, no que concerne à propositura da ação penal, pois, tomando o MPF, pelos mais diversificados meios de sua ação, conhecimento de atos criminosos na ordem tributária, não fica impedido de agir, desde logo, utilizando-se, para isso, dos meios de prova a que tiver acesso. 7. O art. 83, da Lei ${ }^{\circ}$ 9430/1996, não define condição de procedibilidade para a instauração da ação penal pública, pelo Ministério Público. 8. Relevância dos fundamentos do pedido não caracterizada, o que é bastante ao indeferimento da cautelar. 9. Medida cautelar indeferida." (STF, ADIN 1.571-1/MC, Rel. Ministro Néri da Silveira, Brasília, 20 de mar. de 1997.)

Analisando esta decisão, entendeu-se que, na época, não suspendeu a vigência do art. 83, mas também não retirou a possibilidade do MP oferecer denúncia antes da representação da autoridade administrativa, pois a norma destinava-se exclusivamente aos agentes fazendários. ${ }^{21}$

Há quem diga, na verdade, que tal decisão tornava a norma inútil, pois se o MP poderia intentar ação a qualquer tempo, mesmo com o processo

${ }^{21}$ Posteriormente, o Supremo iria confirmar a liminar, só alterando alguns fundamentos, com base no HC 81.611-DF, passou a aclarar essa questão. Esse será objeto de estudo, mais para frente.

"Ação direta de inconstitucionalidade. 2. Art. 83 da Lei no 9.430, de 27.12.1996. 3. Argüição de violação ao art. 129, I da Constituição. Notitia criminis condicionada "à decisão final, na esfera administrativa, sobre a exigência fiscal do crédito tributário". 4. A norma impugnada tem como destinatários os agentes fiscais, em nada afetando a atuação do Ministério Público. É obrigatória, para a autoridade fiscal, a remessa da notitia criminis ao Ministério Público. 5. Decisão que não afeta orientação fixada no HC 81.611. Crime de resultado. Antes de constituído definitivamente o crédito tributário não há justa causa para a ação penal. O Ministério Público pode, entretanto, oferecer denúncia independentemente da comunicação, dita "representação tributária", se, por outros meios, tem conhecimento do lançamento definitivo. 6. Não configurada qualquer limitação à atuação do Ministério Público para propositura da ação penal pública pela prática de crimes contra a ordem tributária. 7. Improcedência da ação" (STF, ADIN 1.571-1, Rel. Ministro Gilmar Mendes, Brasília, 10 de dez. de 2003) 
administrativo fiscal em andamento, caso ele requisitasse documentos às autoridades fazendárias, as mesmas teriam que fornecê-los. ${ }^{22}$

Mesmo com esse entendimento da Corte Maior, permitindo a deflagração da ação penal, por outros meios que o MP possuir ${ }^{23}$, antes de encerrado o procedimento administrativo, grande parte da doutrina continuou a defender a dependência das esferas, inclusive também, a questão de procedibilidade.

Nessa linha de raciocínio, versa Suzana de Faria Machado Moraes ${ }^{24}$ :

“Se o art. 83 da Lei 9430/96 estabelece que o momento para o encaminhamento dos papeis necessários para que o Ministério Público ofereça denúncia se dá somente após a decisão final na esfera administrativa, é porque não deseja que a ação penal seja instaurada antes do final do processo administrativo, e sendo assim, é claro que a finalidade do referido artigo foi criar uma condição de procedibilidade para a ação penal."

Esse entendimento, de não considerar a letra da Lei supérflua, havendo a necessidade de interpretá-la como está descrito, também foi alvo de comentários, como bem assevera o ex-Ministro Edson Vidgal ${ }^{25}$ :

\begin{abstract}
"Representação fiscal para fins penais não pode ser entendida, à luz do Direito Processo Penal, como simples comunicação do fisco, apenas uma notícia crime para o Ministério Público proceder conforme achar melhor. Representação fiscal para fins penais há de ser entendida como condição de procedibilidade, sim. A expressão representação fiscal para fins penais - se reveste de condição técnica, não cabendo outra leitura, senão a que apreenda o seu sentido técnico."
\end{abstract}

Concluiu o autor que, assim, não se valer dessa interpretação, seria votar o dispositivo a uma ociosidade, tornando absolutamente supérflua a norma. ${ }^{26}$

\footnotetext{
${ }^{22}$ Nesse sentido, MORAES, Suzane de Farias Machado. Op. cit. 92

${ }^{23}$ O Magistrado Agapito Machado é um dos que seguiram esse entendimento do Supremo. (MACHADO, Agapito. Nos crime fiscais/tributários a oferta da denúncia deve aguardar o término do procedimento administrativo fiscal? Revista Dialética de Direito tributário, São Paulo, nº 29, p. 7-9, fev. 1998)

${ }^{24}$ MORAES, Suzane de Farias Machado. Op. cit. 93

${ }^{25}$ VIDGAL, Edson Carvalho. Op. cit. p. 454.

${ }^{26}$ Nesse sentido, AZEVEDO, David Teixeira de. Op. cit. p 477.
} 


\title{
2.3.2 - Questão Prejudicial Heterogênea
}

Outra corrente enfocava na tese de que o procedimento administrativo fiscal deveria ser caracterizado como uma questão prejudicial de mérito, pois diferente da condição de procedibilidade, que trata de uma questão processual, a prejudicial heterogênea trataria de questão material.

Com efeito, os artigos 92 e 93 do CPP dispunham que se o juiz entender existir controvérsia sobre a existência de infração no juízo cível deverá o mesmo suspender o curso da ação penal, até que aquela seja resolvida definitivamente, por decisão transitada em julgado. ${ }^{27}$

Assim, para os filiados a esta corrente, deveria o juiz criminal, suspender o curso da ação penal que apurasse a prática de crimes contra a ordem tributária, ao receber notícia de haver litígio na esfera administrativa, sobre a constituição do crédito tributário.

Filiado a essa corrente, entende Eduardo Reale Ferrari, em seu artigo publicado no Instituo Brasileiro de Ciências Criminais ${ }^{28}$ :

\begin{abstract}
"Parece-nos que a solução a ser conferida para tormentosa discussão já está presente na nossa atual legislação penal e processual penal, bastando reconhecer-se a dúvida tributária como verdadeira questão prejudicial heterogênea do procedimento criminal-fiscal. Partindo do pressuposto de que a persecução penal instaurada pelo Ministério Público está dependente da certeza do débito tributário, configura-nos possível qualificar o tributo como antecedente lógico-jurídico da questão penal, objeto do processo criminal fiscal."
\end{abstract}

\footnotetext{
${ }^{27}$ Art. 92. Se a decisão sobre a existência da infração depender da solução de controvérsia, que o juiz repute séria e fundada, sobre o estado civil das pessoas, o curso da ação penal ficará suspenso até que no juízo cível seja a controvérsia dirimida por sentença passada em julgado, sem prejuízo, entretanto, da inquirição das testemunhas e de outras provas de natureza urgente.

Art. 93. Se o reconhecimento da existência da infração penal depender de decisão sobre questão diversa da prevista no artigo anterior, da competência do juízo cível, e se neste houver sido proposta ação para resolvê-la, o juiz criminal poderá, desde que essa questão seja de difícil solução e não verse sobre direito cuja prova a lei civil limite, suspender o curso do processo, após a inquirição das testemunhas e realização das outras provas de natureza urgente.

${ }^{28}$ FERRARI, Eduardo Reale. A prejudicialidade e os crimes tributários. Boletim IBCCRIM, São Paulo, $\mathrm{n}^{\circ} 50$, p. 06, jan. 1997, p. 06.
} 
Insta frisar, que é mencionada a prejudicialidade somente quanto à suspensão da ação penal, e não o impedimento da deflagração desta, pois os tipos previstos nos artigos $1^{\circ}$ e $2^{\circ}$ da Lei 8137/90, utilizam-se da fraude como meio de suprimir, ou reduzir tributos.

Assim, aduzem Aloísio Firmo Guimarães da Silva e Paulo Fernando Correa, que o Auto de infração fiscal lavrado contra o contribuinte serviria como suporte probatório mínimo para que o Ministério Público formulasse acusação penal, cujo conteúdo material espelharia o atributo da presunção de legitimidade dos atos do Poder Público. ${ }^{29}$

Contudo, evidencia-se que essa presunção seria iures tantum, uma vez que o contribuinte poderia confirmar ao longo da ação fiscal que os documentos utilizados não eram inidôneos e que, assim, não houve supressão e redução de tributos. $^{30}$

Por oportuno, não impediria o oferecimento de denúncia, mas, indiscutivelmente, seria relevante para ação penal, sendo qualificada, pelos mesmos, como uma questão prejudicial. Dessa forma estaria caracterizada uma real interdependência entre as instâncias penal e administrativa fiscal, eis que a confirmação da veracidade dos documentos pela autoridade fiscal ensejaria o cancelamento do Auto de Infração, desfigurando o delito imputado aos agentes, e, consequentemente, conduziria a improcedência da ação penal. $^{31} / 32$

\footnotetext{
${ }^{29}$ SILVA, Aloísio Firmo Guimarães da. \& CORREA, Paulo Fernando. Considerações sobre a natureza jurídica da norma prevista no art. 83 da Lei 9430/96. Revista Brasileira de Ciências Criminais. São Paulo, v.6, no 23, p.147-154, jul./set 1998 p. 150

${ }^{30}$ Ibid. p. 151

${ }^{31}$ Ibid, p. 151

${ }^{32}$ Insta frisar, que os autores só consideravam a interdependência das esferas, quando a matéria versase somente quanto à própria existência do crédito tributário, pela utilização da fraude, e não quanto ao
} 
Todavia, também entendiam, Aloísio Guimarães e Paulo Fernando Correa, que a prova da idoneidade do documento poderia ser feita nos próprios autos da ação penal, não ficando o juízo restrito ao aguardo da decisão confirmatória proferida na seara fiscal, mas em havendo, prejudicaria a esfera criminal, e extinguiria a ação penal.

A contrário senso, Hugo de Brito Machado, novamente com seu vasto conhecimento jurídico, ensina que, caso se entenda por uma questão prejudicial, não poderia o Ministério Público promover a ação penal, antes de concretizado o quantum devido pelo contribuinte, pois não é de competência do direito Criminal definir o que é tributo, e sim do direito Tributário. ${ }^{33}$

Por outro turno, o ilustre Sub-Procurador da República, Claudio Fonteles, asseverava que a questão posta "a decisão de autoridade diversa do juiz da ação penal", versando sobre a constituição, ou não, do crédito tributário, se não afirma, por óbvio impede a afirmação de que houve supressão, ou redução de tributos, incidindo, dessa maneira, sobre a tipicidade penal, daí porque se constitui em questão prejudicial heterogênea, pois sua decisão está em autoridade diversa do juiz da ação penal. ${ }^{34}$

O douto Sub-Procurador demonstra em termos práticos a questão da prejudicial heterogênea: quando, por exemplo, um acusado apresenta, na sede penal, os documentos sobre a decisão administrativa de não constituição do crédito tributário, e o Ministério Público por sua vez, representando a sociedade, apresenta, também documentalmente, a prova do ajuizamento de ação cível a questionar a conclusão administrativa. ${ }^{35}$

total devido, pois se realmente houve tributo suprimido, ou reduzido, estaria configurado o crime, e, portanto, o regular prosseguimento da ação penal.

${ }^{33}$ MACHADO, Hugo de Brito. Op. cit. p. 232/233

${ }^{34}$ FONTELES, Claudio. A constituição do crédito tributário não é condição objetiva de punibilidade aos delitos contra a ordem tributária. Revista dos Tribunais, v. 91, n796, p. 492-497, fev. 2002. p. 497

${ }^{35}$ Ibid, p. 497 
Dessa forma, a atitude cabível não poderia ser outra, senão aplicar a norma disposta no artigo 93 do CPP, a qual já mencionamos anteriormente, para suspender o curso da ação penal até o deslinde da esfera cível, no caso, na esfera administrativa.

Em outro enfoque, Ives de Gandra Martins, em seu artigo sobre a procedibilidade penal a luz da Lei $9430 / 96^{36}$, analisa a questão dissertando de forma clara sobre o seu posicionamento, quanto ao momento em que se constitui definitivamente o crédito tributário, sob a análise do artigo 142 do Código tributário nacional, in verbis:

“Art. 142. Compete privativamente à autoridade administrativa constituir o crédito tributário pelo lançamento, assim entendido o procedimento administrativo tendente a verificar a ocorrência do fato gerador da obrigação correspondente, determinar a matéria tributável, calcular o montante do tributo devido, identificar o sujeito passivo e, sendo caso, propor a aplicação da penalidade cabível."

Assim, argumenta o renomado jurista que, o crédito tributário está definitivamente constituído desde o seu lançamento. Ocorre que para fins de cobrança do Fisco, bem como para apuração de crimes contra ordem tributária, deverá ser verificado se houve a interposição de algum recurso na esfera administrativa, pois como alude o artigo 151, III do CTN, a exigibilidade do crédito estará suspensa. ${ }^{37}$

Ocorre que o STF possuía posicionamento contrário, afirmando que o crédito estará definitivamente constituído após a decisão administrativa final irrecorrível, tanto que, para o Excelso Pretório, essa seria a melhor posição para contar o início da prescrição para a cobrança do crédito pela Fazenda.

\footnotetext{
${ }^{36}$ MARTINS, Ives de Gandra da Silva. A procedibilidade a luz da lei 9.430/96. Revista Brasileira de Ciências Criminais, São Paulo, v. 6, n23, p 147-154, jul/set.1998.

${ }^{37}$ Art. 151. Suspendem a exigibilidade do crédito tributário: III - as reclamações e os recursos, nos termos das leis reguladoras do processo tributário administrativo
} 
Com efeito, entendeu o autor que, de acordo com o posicionamento adotado pelo Supremo, ficou estabelecida uma clara questão prejudicial, pois se a constituição do crédito só se dará no final do procedimento administrativo, nenhum contribuinte poderá ser condenado por crime tributário, antes disso. ${ }^{38}$

E conclui esclarecendo que a Corte Maior apenas ofertou a possibilidade do Ministério Público dar início ao processo crime, sem poder terminá-lo ${ }^{39}$, pois caso contrário estaria reformulando sua jurisprudência anterior, pela qual, enquanto não houvesse constituição definitiva do crédito tributário, não poderia haver prescrição contra a Fazenda, que ainda estaria para definir se tinha ou não o crédito respectivo. ${ }^{40}$

Ratificando esse raciocínio leciona Andreas Eisele no sentido de que a esfera administrativa não constituía condição de procedibilidade, mas sim, requisito à propositura da ação penal. ${ }^{41}$

É necessário fazer uma análise de em qual momento se constatará tal requisito, pois sendo antes do início do processo penal, a denúncia não poderá ser recebida por faltar justa causa, enquanto que caso a dúvida quanto ao crime se apresentar após o recebimento desta, este poderá ser suspenso como disposto no artigo 93 do CPP.

Por fim, conclui o autor que: "Trata-se de uma questão prejudicial de mérito, pois a decisão referente à elementar do tipo penal depende da verificação de situação jurídica de competência de outro órgão julgador." 42

\footnotetext{
${ }^{38}$ MARTINS, Ives de Gandra da Silva. Op. cit. p.224

${ }^{39}$ Também entendendo a necessidade de aplicação do art. 93 do CPP.

${ }^{40}$ MARTINS, Ives de Gandra da Silva. Op. cit. p.224

${ }^{41}$ ANDREAS, Eisele. A representação fiscal e os crimes contra ordem tributária. Revista Dialética de Direito Tributário. São Paulo, n. 44, p.21-30, maio 1999, p. 23

${ }^{42}$ Ibid. p. 23
} 


\subsection{3 - Condição Objetiva de Punibilidade}

É de se notar que, realmente, a definição da natureza jurídica da representação fiscal, no que tange ao esgotamento da esfera administrativa, era um tema bastante discutido, tanto que chegamos agora no terceiro viés doutrinário que buscava solucionar a questão.

Não há dispositivo expresso na Lei penal brasileira que defina com precisão o que seria uma condição objetiva de punibilidade.

Assim, seguindo novamente os ensinamentos de Mirabete, entendemos que, às vezes, "a punibilidade, por razões de política criminal, está na dependência do aperfeiçoamento de elementos ou circunstâncias não encontradas na descrição típica do crime e exteriores à conduta." 43

São chamadas de objetivas, pois independem de estarem cobertas pelo dolo do agente. Deve-se seguir o entendimento de que se constituindo a condição objetiva de punibilidade de fato futuro e incerto, não coberto pelo dolo do agente, será esta exterior ao tipo, e por conseqüência, ao crime. ${ }^{44} 45$

Em linha não muito diferente, assevera Luiz Regis Prado que o delito seria uma ação ou omissão típica, antijurídica e culpável, estando a punibilidade fora do conceito analítico do delito. E quando houvesse a realização de um ilícito penal, o direito de punir do Estado, que antes era abstrato, se tornaria concreto, surgindo a possibilidade jurídica de se impor à pena. ${ }^{46}$

\footnotetext{
${ }^{43}$ MIRABETE, Julio Fabrini. Op. cit. p. 107

${ }^{44}$ Ibid, p. 107

45 A sentença declaratória de falência em relação aos crimes falimentares (nas quais a ação é anterior a decisão), desde que a conduta típica não tenha sido causa da quebra, é um bom exemplo de condição objetiva de punibilidade. Outro exemplo é no caso da circunstância do fato punível no país em que foi praticado e estar incluído entre aqueles pelos quais a legislação do Brasil autoriza a extradição nos crimes praticados fora do território nacional.

46 PRADO, Luiz Regis. Apontamentos sobre a punibilidade e suas condicionantes positiva e negativa. Revista dos Tribunais, São Paulo, v. 89 , n.776,p. 440-452, jun. 2000. p. 441
} 
Em sua obra, o ilustre Professor sustenta que as condições objetivas de punibilidade não constituem requisitos do delito, mas apenas dizem respeito à possibilidade de imposição da pena, posto que o crime já estaria perfeito em todos os seus elementos estruturais. E conclui o autor:

"Logo, a função dessas condições não é certamente a de permitir a punibilidade de um delito pelo seu concurso ao aperfeiçoamento do mesmo, mas sim a de excepcionalmente - suspender a punibilidade (submetendo-a a ocorrência de um evento ulterior extrínseco) de um delito já perfeito. "47

Da mesma maneira, segundo o autor, a presença ou não das condições é indiferente para consumação do crime, pois o delito estaria consumado independentemente do advento destas. Contudo, não se verificando as condições objetivas de punibilidade, o delito sequer poderia ser punido, sequer como modalidade tentada. ${ }^{48}$

Destarte podemos concluir que, para haver a punibilidade não basta haver um fato típico, antijurídico e culpável, pois em certos casos será imprescindível que se realize determinada condição para nascer o direito concreto do Estado em punir, qual seja, a condição objetiva de punibilidade. ${ }^{49}$

Adotando essa linha, o causídico Antonio Carlos Barandier entendia que sem a existência de um tributo devido, não poderia se falar em crimes contra a ordem tributária, sendo o artigo 83 da Lei 9430/96, uma clara condição objetiva de punibilidade..$^{50}$

Por oportuno, antes da vigência desse dispositivo, não eram poucos os casos em que denúncias eram oferecidas, com base em apenas presunções constantes de autos de infrações fiscais, o que além de ferir inúmeros

\footnotetext{
${ }^{47}$ Ibid. p. 444

${ }^{48}$ Ibid. p. 446

${ }^{49}$ MARQUES, José Frederico. Tratado de Direito Penal, vol. 3, 2a ed. São Paulo: Saraiva, 1996, p. 315

${ }^{50}$ BARANDIER, Antonio Carlos da Gama. Condição objetiva de punibilidade e crimes contra o sistema tributário. Boletim IBCCRIM. São Paulo, n. 57, p.13, ago. 1997
} 
princípios constitucionais, também trazia ao contribuinte, diversos constrangimentos, por se ver envolvido em várias e massacrantes etapas de um processo penal.

Tal conduta não se justifica, pois, como concluiu Barandier, a pretensão punitiva, nesses casos, estaria sujeita a condição objetiva, qual seja, a definição do efetivo crédito tributário, a fim de que pudesse nascer o direito concreto de punir do Estado. ${ }^{51}$

Em contrapartida, há quem defenda que jamais a representação físcal poderá ser considerada condição objetiva de punibilidade. ${ }^{52}$

\subsection{4 - Elemento normativo do tipo}

Outra linha de doutrinadores seguiu o entendimento de que para haver a regular aplicação do dispositivo em análise dever-se-ia entender o tributo como elemento normativo do tipo.

De plano, é necessário esclarecer que, na definição dos tipos penais, o legislador utiliza conceitos ditos naturais, bem como conceitos normativos. E, como leciona Hugo de Brito Machado, em outra fantástica obra jurídica, os conceitos naturais seriam aqueles cuja definição não dependeria do conhecimento das normas jurídicas, sendo esses, de linguagem comum. No caso em tela, os termos suprimir e reduzir tributos seriam conceitos naturais, pois qualquer um que não seja intérprete do direito saberia definir os seus

\footnotetext{
${ }^{51}$ Ibid, p. 13

${ }^{52}$ Como elucidado anteriormente, Claudio Fonteles entende que a constituição do crédito tributário seria uma questão prejudicial heterogênea, devendo haver a suspensão do processo, quando necessário, conforme ditames dos artigos 92 , e 93 do CPP. O autor refuta a idéia de condição objetiva de punibilidade, em seu artigo: "A constituição do crédito tributário não ó condição objetiva de punibilidade aos delitos contra a ordem tributária", por entender que o crédito tributário é elemento constitutivo do fato, não aceitando a tese de que virá um elemento futuro e incerto para confirmar a necessária punibilidade do agente. Para o Procurador, o que prevaleceria seria a necessidade da esfera cível/administrativa ser a competente para julgar a questão do tributo devido.
} 
significados. Diferentemente do que ocorre com o conceito tributo, e assim entenderíamos que suprimir e reduzir seriam conceitos naturais, enquanto tributo seria um conceito normativo. ${ }^{53}$

E concluiu o autor, com suas sábias palavras: "Em síntese, o conhecimento adequado dos conceitos naturais depende apenas do conhecimento geral, enquanto que o conhecimento dos conceitos normativos depende do conhecimento científico." 54

Desta maneira, para analisarmos melhor essa questão, devemos ter em mente que o mais importante dos conceitos normativos utilizados na definição dos crimes contra a ordem tributária é o conceito de tributo, sendo este elemento normativo do tipo.

Mas não é só, não basta pensar no tributo simplesmente, devemos pensar no elemento normativo como um tributo devido. ${ }^{55} \mathrm{Ou}$ seja, um crédito tributário regularmente constituído, tendo passado por todas as etapas do contencioso administrativo, demonstrando que o sujeito passivo é realmente devedor daquele tributo e naquela quantidade.

Dessa maneira, assevera Rogério Tucci, tanto antes quanto após a edição da Lei 9.430 de 1996, que o melhor entendimento acerca dos tipos previstos no

${ }^{53}$ MACHADO, Hugo de Brito. Crimes contra a ordem tributária. 2. ed.- São Paulo: Atlas, 2009. p 348

${ }^{54}$ Ibid, p.348

${ }^{55}$ Dito isto, para definirmos o que é exatamente tributo devido, deveríamos abordar a discussão acerca do momento em que se estaria constituído definitivamente o crédito tributário, e ,como aqui não é o melhor momento para isso, ficaremos com a definição de Luiz Emygdio F. da Rosa Jr., que nos parece a melhor cabível: "O crédito tributário considera-se constituído definitivamente com a notificação regular do lançamento ao sujeito passivo e o decurso do prazo legal sem pagamento ou impugnação. No caso de o sujeito passivo impugnar o lançamento e havendo decisão administrativa definitiva a favor do fisco, após o decurso do prazo legal a contar da notificação dando-lhes ciência da decisão (CTN, art. 201). O crédito tributário só se torna exigível com a sua constituição definitiva, mas sua exeqüibilidade depende do ato da inscrição, transformando o crédito tributário em dívida ativa tributária e fazendo nascer a certidão da dívida ativa. O pressuposto para inscrição do crédito tributário é, portanto, sua constituição definitiva (CTN, art. 201)" (ROSA JUNIOR, Luiz Emygdio F. da. Manual de direito tributário. Rio de Janeiro: Renovar, 2009. p. 361) 
art. $1^{\circ}$ da Lei $8137 / 90$, é considerar como elemento normativo objetivo do tipo: ${ }^{.5}$

"o elemento normativo objetivo do tipo insculpido no artigo $1^{\circ}$ da Lei ${ }^{\circ} 8137$ de 1990, consiste como visto, na SUPRESSÃO, ou REDEUÇÃO, DE TRIBUTO DEVIDO, mediante as anotações fraudatórias nele especificadas, quais sejam as concernentes à atuação ou omissão relativa a informação, declaração falsa, registro, contabilização ou documentação falsa ou inexata, a respeito da operação de qualquer natureza, sobre que incidente tributo ou contribuição social" (grifos do autor)

Não é outra a conclusão de Leônidas Ribeiro Scholz asseverando que a Lei abraçou explicitamente o entendimento de que a exigibilidade do tributo é fato que compõe, ao lado das condutas respectivamente descritas, a própria tipicidade dos delitos contra a ordem tributária. ${ }^{57}$

Esta tese ganha respaldo no tocante ao Direito Penal Tributário ser considerado um direito de superposição na medida em que a norma penal, no campo tributário, deverá considerar não apenas comportamentos e fatos, mas comportamentos e fatos regulados pelo Direito Tributário. ${ }^{58}$

Assim, fica inimaginável aplicar o direito penal, passando por cima de conceitos próprios do direito Tributário, no caso em tela, a questão de iniciar um processo penal, sem antes esgotar a esfera administrativa, na hipótese de não haver um tributo devido pelo contribuinte.

Da mesma maneira, não se estaria cerceando a atividade do titular exclusivo da ação penal, muito menos desfigurando o caráter de ação pública, caráter esse consagrado na Súmula 609 do Supremo Tribunal Federal, bem como disposto expressamente no art. 15 da própria Lei que rege os crimes contra ordem tributária, a Lei 8137/90. Estaria apenas exigindo a comprovação

\footnotetext{
${ }^{56}$ TUCCI, Rogério Lauria. Breve estudo sobre a ação penal relativa a crimes contra a ordem tributária. Revista do Advogado, São Paulo, n. 53, p7-17, out. 1998.

${ }^{57}$ SCHOLZ, Leônidas Ribeiro. Crimes contra a ordem tributária e persecução penal. Revista dos Tribunais. São Paulo, v.86, n. 739, p.487-494, maio 1997. p. 489

${ }^{58}$ Nesse sentido, SANTOS JUNIOR, Belisário dos. Prévio esgotamento da via administrativa e ação penal contra a ordem tributária. Boletim IBCCrim. São Paulo, n 47, p. 05, out. de 1996.
} 
da existência de ilícito fiscal para que se tenha comprovado a materialidade do ilícito penal, configurando assim, clara condição da ação. ${ }^{59}$

Com efeito, assevera Tucci, que com "clareza meridiana" não poderia o artigo 83 da Lei 9.430/96 estabelecer nenhuma condição de procedibilidade, tampouco criar uma nova espécie de prejudicialidade relativa. E ainda enfatiza que tornou letra escrita o que já se deveria entender como lógica: "enquanto não tornada certa a exigência do ilícito tributário, não se pode supor praticado o ilícito penal daquele decorrente.” 6061

Justifica-se dessa maneira, por entender que, não obstante o termo "representação fiscal" aluda a uma contextura processual, a verificação da existência de um tributo devido traduziria a nítida natureza material do dispositivo, sendo, por sua vez, elemento configurador da justa causa para a ação penal.

Por oportuno, percebe-se que pensar dessa maneira é uma questão de coerência e de segurança jurídica, pois é justo e razoável que somente depois de constituído de modo definitivo o tributo devido possa se iniciar um processo penal. $^{62}$

E, dessa forma, não havendo tipicidade, pressuposto primeiro da eficácia processual das normas penais incriminadoras, serão inadmissíveis não só a ação penal, mas também, previamente, a proibição de qualquer notítia criminis e de instauração de procedimentos investigatórios, via inquéritos policiais. ${ }^{63}$

\footnotetext{
${ }^{59}$ TUCCI, Rogério Lauria. Op. cit. p.12

${ }^{60}$ Ibid, p. 12

${ }^{61} \mathrm{O}$ autor ainda dispõe que o único objetivo do art. 83 da lei 9430/96 foi de corrigir o desacerto da norma contida nos artigo $1^{\circ}$ e $3^{\circ}$, parágrafo $2^{\circ}$ do Decreto 982, de 12 de novembro de 1993 (já mencionado por analisado no início desse trabalho), que determinava as autoridades fiscais o envio de representação para fins penais ao MP tão $\log$ o fosse expedido o Auto de Infração ou a notificação fiscal de lançamento de débito.

${ }^{62}$ Nesse sentido, GOMES, Luiz Flávio. Reforma tributária e prévio exaurimento da via administrativa nos crimes tributários. Boletim IBCCRIM. São Paulo, v. 7, n. 86, p.3, jan. 2000.

${ }^{63}$ SCHOLZ, Leônidas Ribeiro. Op. cit. p. 490.
} 
Em outro enfoque, Luiz Flavio Gomes, vê como temerária a não obediência ao término na esfera administrava para a deflagração da ação penal, pois, como ocorria antigamente, ao haver denúncia antes de esgotada a esfera fiscal, ocorreria o absurdo de se chegar a uma condenação penal, e ao mesmo tempo ver reconhecida à inexistência do tributo, que antes era questionável. ${ }^{64}$

Além disso, outra drástica consequiência de denúncias prematuras era o fato de coibir o contribuinte de exercer o seu direito de pagar o tributo devido, e ver extinta a punibilidade, como era disposto no artigo 34 da Lei 9.249/95 ${ }^{65}$. Isso porque o citado artigo só permitia a extinção da punibilidade, se o tributo fosse pago antes da denúncia. E, como alguém pode fazer um pagamento de algo que ainda não se tem quantificado, uma vez que somente após o término do processo fiscal é que se teria o quantum debeatur ${ }^{66}$

Depois de vistas e analisadas, todas as correntes doutrinárias que abordavam o assunto da dependência das esferas penal e administrativo fiscal, concluímos que todas possuíam sua própria fundamentação para se autosustentarem.

Ocorre que, mesmo assim, as jurisprudências dos Tribunais, tanto superiores, quanto inferiores, com raríssimas exceções, discordavam dos fundamentos alegados sobre a necessidade do esgotamento da esfera administrativa para deflagração da ação penal, que continuavam por entender

\footnotetext{
${ }^{64}$ GOMES, Luiz Flávio. Op. cit. p.3

65 Esse dispositivo vigorava à época que publicou o artigo citado, hoje em dia, a extinção da punibilidade, pelo pagamento do tributo pode se dar a qualquer momento, como disposto no parágrafo $2^{\circ}$ do artigo $9^{\circ}$ da Lei 10684/2003: "Art. $9^{\circ}$ É suspensa a pretensão punitiva do Estado, referente aos crimes previstos nos arts. $1^{\circ}$ e $2^{\circ}$ da Lei $n^{\circ} 8.137$, de 27 de dezembro de 1990, e nos arts. 168A e 337A do Decreto-Lei $\mathrm{n}^{\circ} 2.848$, de 7 de dezembro de 1940 - Código Penal, durante o período em que a pessoa jurídica relacionada com o agente dos aludidos crimes estiver incluída no regime de parcelamento.

$\S 2^{\circ}$ Extingue-se a punibilidade dos crimes referidos neste artigo quando a pessoa jurídica relacionada com o agente efetuar o pagamento integral dos débitos oriundos de tributos e contribuições sociais, inclusive acessórios."

${ }^{66}$ GOMES, Luiz Flávio. Op. cit. p. 3
} 
pela independência e autonomia das mesmas. Tal assertiva se justifica pela ementa de alguns julgados abaixo:

"PROCESSUAL PENAL. CRIMES CONTRA A ORDEM TRIBUTARIA. LEI N. 9.430/96. AÇÃO PENAL. REPRESENTAÇÃO FISCAL. ATO PRESCINDIVEL.

- Em sede crimes contra a ordem tributaria, a representação fiscal a que se refere o art. 83 da lei n. 9.430/96 não e condição de procedibilidade para a promoção da ação penal, podendo o Ministério Publico, no exercício de sua competência legal, valer-se de quaisquer outros elementos informativos da ocorrência do delito para oferecer a denuncia. - Recurso Ordinário desprovido." (STJ, RHC 6898, Rel. Ministro Vicente Leal, Brasília, 27 out. de 1997.)

\section{"PROCESSUAL PENAL. CRIME DE SONEGAÇÃO FISCAL. INSTAURAÇÃO DA AÇÃO PENAL. SUSPENSÃO PARA AGUARDAR DECISÃO ADMINISTRATIVA. FALTA DE AMPARO LEGAL.}

As instancias penal e administrativa não guardam dependência uma da outra e nem as disposições do código de processo penal autorizam a suspensão, de oficio, da ação penal no aguardo de solução a ser proferida no procedimento administrativo. Firme, por outro lado, a jurisprudência segundo a qual a apuração do debito fiscal não e condição de procedibilidade da ação penal." (STJ, RESP 59512, Rel. Ministro Jesus Costa Lima, Brasília, 26, abr. de 1995.)

"EMENTA: CONSTITUCIONAL. PROCESSUAL PENAL. PENAL. CRIME CONTRA A ORDEM TRIBUTÁRIA. REPRESENTAÇÃO FISCAL. SUSPENSÃO DO CURSO DA AÇÃO PENAL: DECISÃO DEFINITIVA DO PROCEDIMENTO ADMINISTRATIVO FISCAL. Lei 8.137, de 1990, artigos $1^{\circ}, 2^{\circ}$ e 14; Lei 8383, de 1991, artigo 98; Lei 9249, de 1995, art. 34; Lei 9430, de 1996, art. 83 e seu parágrafo único. I - A representação fiscal a que se refere o art. 83, da Lei 9.430/96, estabeleceu limites para os órgãos da administração fazendária, ao determinar que a remessa ao Ministério Público dos expedientes alusivos aos crimes contra a ordem tributária, definidos nos arts. $1^{\circ}$ e $2^{\circ}$, da Lei 8.137/90, somente será feita após a conclusão do processo administrativo fiscal. Todavia, não restringiu o citado dispositivo legal a ação do Ministério Público (C.F., art. 129, I). II. Precedente do STF: ADIn 1571-DF (medida cautelar), Rel. Min. Néri da Silveira, Plenário, 20.03.97. III. - No caso, não há falar em extinção da punibilidade pelo pagamento do tributo e acessório: Lei 8.137/90, art. 14, revogado pela Lei 8.383/91, art. 98. Lei 9.249/95, art. 34; Lei 9.430/96, art. 83, parág. único. IV. - H.C. indeferido." (STF, HC 75.723, Rel. Ministro Carlos Velloso, Brasília, 18 nov. de 1997.)

Acontece que houve uma reviravolta no entendimento jurisprudencial, após

o extenso e prolongado debate do Habeas Corpus $\mathrm{N}^{\circ}$ 81.611-DF, julgado no

Supremo Tribunal Federal, o qual será analise no próximo Capítulo. 


\section{3 - A ATUAL POSIÇÃO DO STF ACERCA DA MATÉRIA}

Após diversos e prolongados debates e discussões sobre a questão da representação fiscal para fins penais, e a independência, ou não, das esferas, já era hora do Supremo Tribunal Federal dar um ponto final na matéria, encerrando o assunto.

Dessa forma, com a decisão proferida nos autos do Habeas Corpus 81.611DF, de relatoria do Ministro Sepúlveda Pertence, a jurisprudência do Excelso Pretório estava por dar uma guinada de $180^{\circ}$ graus em seu entendimento, pondo fim nesta discussão que se arrastava por anos - ou, pelo menos, era o que se esperava - como demonstrado pela ementa abaixo:

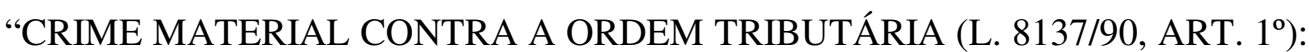
LANÇAMENTO DO TRIBUTO PENDENTE DE DECISÃO DEFINITIVA DO PROCESSO ADMINISTRATIVO: FALTA DE JUSTA CAUSA PARA A AÇÃO PENAL, SUSPENSO, PORÉM, O CURSO DA PRESCRIÇÃO ENQUANTO OBSTADA A SUA PROPOSITURA PELA FALTA DO LANÇAMENTO DEFINITIVO.

1. Embora não condicionada a denúncia à representação da autoridade fiscal (ADInMC 1571), falta justa causa para a ação penal pela prática do crime tipificado no art. $1^{\circ}$ da L. 8137/90 - que é material ou de resultado -, enquanto não haja decisão definitiva do processo administrativo de lançamento, quer se considere o lançamento definitivo uma condição objetiva de punibilidade ou um elemento normativo de tipo. 2. Por outro lado, admitida por lei a extinção da punibilidade do crime pela satisfação do tributo devido, antes do recebimento da denúncia (L. 9249/95, art. 34), princípios e garantias constitucionais eminentes não permitem que, pela antecipada propositura da ação penal, se subtraia do cidadão os meios que a lei mesma lhe propicia para questionar, perante o Fisco, a exatidão do lançamento provisório, ao qual se devesse submeter para fugir ao estigma e às agruras de toda sorte do processo criminal.

3. No entanto, enquanto dure, por iniciativa do contribuinte, o processo administrativo suspende o curso da prescrição da ação penal por crime contra a ordem tributária que dependa do lançamento definitivo."

(STF, HC 81.611-8, Rel. Ministro Sepúlveda Pertence, Brasília, 10 dez. de 2003.) 


\section{1 - Análise do HC 81.611 - DF}

Pela importância do julgado em baila, e pelos temas levantados na discussão do mesmo, mister necessário analisá-los separadamente, para melhor compreendermos a essência do entendimento da Corte Maior.

\subsection{1 - 0 caso}

Tratava-se de Habeas Corpus impetrado em favor de paciente que havia sido denunciado pelo Ministério Público Federal em 18/06/1997, pela suposta prática de crimes contra a ordem tributária, descritos no art. $1^{\circ}$, I e II, da Lei 8137/90. Segundo constava da denúncia, o paciente teria omitido informações às autoridades fazendárias, suprimindo tributos relativos à empresa administrada por ele. A omissão de informação caracterizaria fraude tributária, uma vez que a empresa teria omitido operações em documentos e livros exigidos. A suposta receita auferida, que não teria sido lançada nos registros contábeis, seria proveniente da venda de trezentos e sessenta imóveis.

Visando o trancamento da ação penal em razão do não esgotamento da esfera administrativa, havendo pendência no processo administrativo fiscal, foi impetrado em favor do paciente Habeas Corpus perante o TRF da $3^{\text {a }}$ Região, que denegou a ordem. Os patronos do paciente insurgiram-se contra essa decisão, interpondo Recurso Ordinário, desprovido por unanimidade pela $5^{\mathrm{a}}$ Turma do STJ, e Recurso Extraordinário ao STF, que não foi admitido. Contra a decisão que denegou a ordem no RHC, foi interposto o presente Habeas Corpus em análise. 
Insta frisar, que constava tanto do relatório do Ministro Relator Sepúlveda Pertence, como dos apontamentos feitos pela Min. Ellen Gracie ${ }^{67}$, que à época da impetração do habeas corpus, em 26/12/2001, passados mais de dez anos dos fatos denunciados pelo MPF, ainda não tinham sido lançados em definitivo os tributos supostamente sonegados, à época do julgamento, já reduzidos para aproximadamente um terço do valor originalmente lançado, em razão das decisões administrativas até então proferidas.

Os impetrantes ainda deixaram claro que naquele momento aguardava-se a formalização e publicação da decisão do acórdão da $7^{\mathrm{a}}$ Câmara do Primeiro Conselho de Contribuinte, que havia dado parcial provimento ao recurso voluntário, e que dessa decisão caberia recurso a Câmara Superior de Recursos Fiscais, e ainda, possivelmente recurso ao Ministro da Fazenda.

Visto isto, podemos adentrar os temas relevantes abordados na discussão, quais sejam: a distinção entre crime formal e material; a definição do lançamento definitivo; extinção da punibilidade pelo pagamento; e a questão da prescrição.

\subsection{2 - A Natureza de Crime Material}

O primeiro ponto trazido pelo ilustre Ministro Sepúlveda Pertence, para resolver a questão da existência ou não de justa causa para a denúncia nos crimes contra a ordem tributária, antes de encerrada a controvérsia na via administrativa, é saber se a Lei penal incriminadora trata de crime material ou de crime formal. ${ }^{68}$

\footnotetext{
${ }^{67}$ HC 81.611-8, Acórdão p.91 e p.145

${ }^{68}$ Distinguem-se crimes materiais dos crimes formais no que tange ao resultado. Nos materiais, ou de resultado, o tipo descreve a conduta cujo resultado integra o próprio tipo penal, isto é, para a sua consumação é indispensável a produção de um dano efetivo, enquanto que nos formais, ou de mera
} 
$\mathrm{Na}$ vigência da Lei 4.729/65, os crimes ali tipificados como crimes de sonegação fiscal possuíam cunho completamente formal. Diferentemente do que a doutrina pátria e nossos tribunais entendem acerca dos crimes previstos na Lei 8137/90 que, segundo Pertence, criou um tipo de crime de resultado.

Esse entendimento se dá no sentido de que só restaria caracterizado o crime, se realmente houvesse sido apurada uma supressão ou redução de tributos, não bastando apenas o contribuinte praticar as fraudes - meios - para obter o resultado final, pois a efetiva supressão ou redução do tributo passaria a ser elemento constitutivo do tipo penal, que se aperfeiçoaria mediante as condutas dos incisos do artigo $1^{\circ}$ da Lei 8137/90. ${ }^{69}$

Ocorre que, a tese de crime material contra a ordem tributária, tanto para Pertence, quanto para a grande maioria dos doutrinadores, só seria aplicada ao artigo $1^{\circ}$ da Lei 8137/90, considerando as condutas elencadas no artigo $2^{\circ}$ como formais.

Em posicionamento contrário Claudio Fonteles, que representava o MPF no caso em tela, era adepto da linha que entendia serem ambos os crimes dos artigos $1^{\circ}$ e $2^{\circ}$ crimes materiais, tanto que deixou claro em seu parecer sobre a

conduta, sua consecução independe dos efeitos que viessem a ocorrer, sem a necessidade do resultado para a consumação dos crimes, ou seja, a mera conduta já é suficiente para consumar o crime.

${ }^{69}$ Art. $1^{\circ}$ : Constitui crime contra a ordem tributária suprimir ou reduzir tributo, ou contribuição social e qualquer acessório, mediante as seguintes condutas: I - omitir informação, ou prestar declaração falsa às autoridades fazendárias; II - fraudar a fiscalização tributária, inserindo elementos inexatos, ou omitindo operação de qualquer natureza, em documento ou livro exigido pela lei fiscal; III - falsificar ou alterar nota fiscal, fatura, duplicata, nota de venda, ou qualquer outro documento relativo à operação tributável; IV - elaborar, distribuir, fornecer, emitir ou utilizar documento que saiba ou deva saber falso ou inexato; V - negar ou deixar de fornecer, quando obrigatório, nota fiscal ou documento equivalente, relativa a venda de mercadoria ou prestação de serviço, efetivamente realizada, ou fornecê-la em desacordo com a legislação. Pena - reclusão de 2 (dois) a 5 (cinco) anos, e multa. Parágrafo único. A falta de atendimento da exigência da autoridade, no prazo de 10 (dez) dias, que poderá ser convertido em horas em razão da maior ou menor complexidade da matéria ou da dificuldade quanto ao atendimento da exigência, caracteriza a infração prevista no inciso V. 
denegação da ordem, nos autos do HC, bem como em seu trabalho doutrinária, já comentado anteriormente. ${ }^{70}$

Por oportuno, concluiu o Ministro Relator que a modalidade do artigo $1^{\circ}$ trata-se de um tipo misto alternativo, porém, de resultado. Significando dizer que qualquer das condutas comissivas ou omissivas descritas nos diversos incisos serve para aperfeiçoar o crime, mas não basta à sua consumação, para a qual não se prescinde de que, de uma ou mais delas, resulte a supressão ou redução do tributo devido. ${ }^{71} 72$

Em sentido contrário, a Ministra Ellen Gracie entendeu que ambos os artigos tratam de crimes de natureza formal, discordando assim do relator, que, por sua vez, interpretou os crimes praticados pelos pacientes como de resultado. E entendeu ainda que, é necessário apurar o resultado líquido ou certo da conduta para que haja a justa causa para a ação penal.

Ocorre que, no julgamento do caso em análise, o posicionamento de Pertence prevaleceu sobre o da Ministra Ellen Gracie, o que se faz necessário esclarecer para melhor analise das futuras controvérsias quanto a este julgado.

\footnotetext{
${ }^{70} \mathrm{Na}$ mesma linha, entendendo ambos os crimes serem materiais: COSTA, Claudio. Crimes de Sonegação Fiscal. Rio de Janeiro: Revan, 2003, p. 48; e MALAN, Diogo. Considerações sobre os crimes contra ordem tributária. Revista dos Tribunais, São Paulo, v. 96, n.865, p.450-481, novembro de 2007, p. 465.

${ }^{71}$ HC 81611-DF, voto Sepúlveda Pertence, p. 20.

${ }^{72}$ Para Gustavo Henrique de Souza Silva, o entendimento adotado no HC 81.611-DF, de só estar caracterizado o crime material quando houver configurada uma lesão efetiva ao Fisco, foi o mais adequado possível aos preceitos constitucionais, consagradores de um direito penal mínimo e subsidiário e, assim, orientado pelo Principio da Lesividade, que limita a intervenção penal as hipóteses de lesão ou risco efetivo de lesão ao bem jurídico penalmente relevante. (SILVA, Gustavo Henrique de Souza e. A relação entre o processo administrativo de constituição de crédito tributário e os crimes de descaminho e de apropriação indébita previdenciária à luz da jurisprudência dos tribunais superiores. In: RESENDE, Sérgio Antonio de; PINTO, Felipe Martins; ESTEVES, Heloisa Monteiro de Moura (Org.). Analise de precedentes criminais do Superior Tribunal de Justiça: estudos em homenagem à Desembargadora Jane Ribeiro Silva. Belo Horizonte: Atualizar, 2009. p. 118.)
} 


\subsection{3 - O Enquadramento da decisão de lançamento definitivo do tributo dentro da estrutura do delito}

Um dos debates centrais objeto do mencionado julgamento foi a discussão do enquadramento da decisão de lançamento definitivo do tributo dentro da estrutura do delito, se elemento normativo do tipo, condição objetiva de punibilidade ou se questão prejudicial heterogênea.

Observa-se que todos os Ministros, de forma unânime, entenderam que não há uma condição de procedibilidade, assim como havia sido decidido no julgamento da ADIn 1571-1, no sentido de que o artigo 83 da Lei 9.430/1996 tinha como destinatários os agentes fazendários, e não o Ministério Público, sendo a ação penal pública, nos crimes contra a ordem tributária, incondicionada, podendo o MP, deflagrar a ação penal por outros meios.

As reflexões sobre esse ponto aprofundaram-se com a discussão sobre a própria natureza jurídica do lançamento tributário, se meramente declaratório, nos moldes do artigo 113 do CTN, ou constitutivo, nos moldes do artigo 142 do mesmo diploma legal.

Pertence, em seu voto, analisa a questão, entendendo que a competência para constituir o crédito tributário é privativa da Administração Fiscal, e que o crime do artigo $1^{\circ}$, por ser material/de resultado, pressuporia a existência de um tributo, que mediante as condutas prescritas deveria ter sido alvo de supressão, ou redução do agente. Diante disso, não se poderia afirmar, sequer para a denúncia, a ocorrência desse pressuposto enquanto, a respeito, não fosse operado, pelo menos, o efeito preclusivo da decisão final do processo administrativo. 
E continua o ilustre Relator asseverando que o caso em tela tratava-se de hipótese extraordinária, pois a tipicidade, e não só ela, mas também a punibilidade do agente, malgrado típica, estariam subordinadas a decisão de autoridade diversa do juiz da ação penal. Por isso, concluiu que a questão apenas deslocava da esfera da tipicidade para a das condições objetivas de punibilidade. ${ }^{73}$

Dessa maneira, seria na verdade, não usurpar a competência privativa da Administração Publica para o ato de constituição do crédito tributário, sujeito ele mesmo, de resto, ao controle judicial de sua validade, quando se the anteponha pretensão de direito subjetivo violado do contribuinte.

Dissentindo do entendimento exposto pelo Min. Sepúlveda Pertence, a Min. Ellen Gracie entendia que a obrigação tributária de caráter geral e abstrato não era a ocorrência do fato jurídico tributário, e sim a que se continha na Lei. Dessa maneira, quando ocorresse o fato típico nela previsto, a obrigação tributária se concretizava e individualizava.

Dito isto, entendia a Ministra que o tributo era devido em seu vencimento e este prazo tinha cômputo desde a data do fato gerador, e, sendo assim, seja no montante inicialmente levantado pela autuação, seja naquele reduzido pelo Conselho do Contribuinte, o tributo já era devido e deixou de ser atendido no vencimento.

A Ministra questiona o posicionamento adotado por Pertence, pois entendeu que o mesmo deu conseqüência diversa à eficácia preclusiva da decisão administrativa, sendo ela favorável ao contribuinte ou não. Isto porque, com a improcedência da impugnação, a decisão não constituiria elemento essencial do tipo, mas assumiria eficácia puramente declaratória, do tributo devido, com a consequiência de retroatividade do lançamento à data de

\footnotetext{
${ }^{73}$ Os Ministros Nelson Jobim, Gilmar Mendes, acompanharam o relator em seu entendimento.
} 
consumação do fato gerador. E caso a impugnação fosse julgada procedente, afirmando que o contribuinte não supriu, nem reduziu tributo, estaria afastando o juízo positivo de tipicidade da conduta que permitiria ao MP desencadear a ação penal, concluindo a ilustre Ministra ao final, que, no entender do Ministro Pertence, se trataria de uma questão prejudicial, obstando a atuação do Ministério Público, o que, no entendimento da Ministra, não o poderia ser de maneira alguma.

Esses são alguns motivos, dentre outros, que levaram a Ministra, não só a discordar do entendimento do Relator, no que tange a condição objetiva de punibilidade, como também, a votar pela denegação da ordem.

Outro julgador que não se filiou ao posicionamento de Pertence foi Joaquim Barbosa, ao alegar que existia uma dificuldade em conciliar o conceito de condição objetiva de punibilidade com o papel do Fisco no lançamento da obrigação tributária. ${ }^{74}$

Para o Ministro, a decisão da autoridade administrativa acerca da impugnação do contribuinte poderia ter duas naturezas distintas: se, no sentido de indeferir a impugnação do contribuinte e confirmar a existência do débito tributário, constituiria um elemento adicional de comprovação da materialidade do crime; ou, caso contrário, se julgasse procedente a impugnação, a decisão do Fisco constituiria no máximo um elemento de exclusão de tipicidade.

Desse modo, ele não via como condicionar o exercício da ação penal a um evento futuro e incerto, extrínseco ao crime, sendo este o conceito doutrinário das condições objetivas de punibilidade.

\footnotetext{
${ }^{74} \mathrm{O}$ Ministro trouxe em seu voto uma definição dada por Nelson Hungria sobre condições objetivas de punibilidade, em que a punição da conduta ficaria condicionada a certas circunstâncias extrínsecas ao crime. Também colaciona aos autos a definição do crime de induzimento ao suicídio, tratando-se nesses casos com uma infração cuja punibilidade estaria condicionada a verificação de um acontecimento incerto e futuro.
} 
Joaquim Barbosa também ficou receoso, pois caso a administração tributária não se manifestasse passados os cinco anos expostos no parágrafo $4^{\circ}$ do artigo 150 do CTN, haveria a homologação tácita, ficando definitivamente extinto o crédito tributário e, consequentemente, o Fisco estaria impedido de cobrar qualquer fato oponível. Daí o problema em considerar o lançamento definitivo como condição objetiva de punibilidade nos tributos sujeitos ao lançamento por homologação. E dessa maneira, o Ministro se questiona qual seria o fato ou ato jurídico consubstanciador da condição objetiva de punibilidade.

Nesses casos, teríamos um termo objetivo de punibilidade, só que como definido pelo próprio jurista, teríamos um "natimorto", pois ao mesmo tempo em que surgisse o relevante penal, o crédito tributário seria extinto, pois o Fisco não poderia cobrar, por ter incidido o instituto da decadência, fazendo desaparecer o ius puniendi.

Nessa linha de raciocínio, o ilustre Ministro entendeu que essa questão deveria ser tratada como uma questão prejudicial heterogênea, nos moldes do artigo 93 do CPP, pois o lançamento definitivo só condiciona a ação de execução fiscal e, dessa maneira, havendo os requisitos para oferecimento da denúncia, o MP deverá iniciar a ação penal.

Assim, o juiz ao perceber que haveria crédito a ser apurado, deveria suspender o processo, aguardando o lançamento definitivo, e dependendo da decisão administrativa, extinguir a ação penal no mérito, ou retomar o seu curso com a prova do resultado naturalístico de supressão ou redução de tributo.

Por outro turno, segue o Ministro Cesar Peluso, quase que na íntegra, o raciocíno do ilustre Relator, discordando, todavia, somente quanto à definição dada à decisão definitiva do lançamento, entendendo ser a mesma, elemento 
normativo do tipo, pois enquanto não estiverem integrados todos os elementos do tipo penal, não adiantaria fazer prova de nada, porque o fato que for provado será sempre fato atípico, penalmente irrelevante. E concluiu que só com o lançamento definitivo aparece a obrigação exigível, portanto, tributo devido, em que, presentes os demais elementos, configuraria o tipo penal, sendo previamente impossível a propositura da ação penal.

Mesmo diante de toda a discussão, a querela não chegou a ser definida pelos Ministros na oportunidade do julgamento daquele habeas corpus, até porque se entendeu que esta definição seria dispensável para o julgamento do caso concreto. Tanto é verdade, que ficou esse entendimento cristalizado em uma parte da ementa do acórdão: “...enquanto não haja decisão definitiva do processo administrativo de lançamento, quer se considere o lançamento definitivo uma condição objetiva de punibilidade ou elemento normativo do tipo..."75

\subsection{4 - Extinção da punibilidade pelo pagamento}

Entendendo que o fato do caso em exame tratava-se de crime material, outra questão, que foi trazida à baila do debate, versava a respeito da repercussão da previsão de extinção da punibilidade pelo pagamento.

Para Pertence, o artigo 34 da Lei $9249 / 95^{76}$ permitiu que o sujeito ativo do crime pudesse se utilizar do efeito de extinguir a punibilidade do crime contra a ordem tributária, antes do recebimento da denúncia, o que pressuporia a exigibilidade e a liquidez do crédito tributário correspondente.

\footnotetext{
${ }^{75}$ Trecho da EMENTA do HC 81.611 -DF, STF, Rel. Min. Sepúlveda Pertence

76 Art. 34. Extingue-se a punibilidade dos crimes definidos na Lei $\mathrm{n}^{\circ}$ 8.137, de 27 de dezembro de 1990, e na Lei $\mathrm{n}^{\circ} 4.729$, de 14 de julho de 1965, quando o agente promover o pagamento do tributo ou contribuição social, inclusive acessórios, antes do recebimento da denúncia.
} 
Dessa maneira, só a decisão definitiva do procedimento administrativo do lançamento tornaria líquido o crédito tributário e, via de consequiência, permitira ao devedor liberar-se do mesmo pelo pagamento, pois como poderia o suposto acusado pagar o montante do tributo, se ainda não havia sido apurado o quantum debeatur final da obrigação?

Fortalecendo a tese do Min. Pertence, o Min. Nelson Jobim, também entendeu que o pagamento feito pelo contribuinte serviria de instrumento de defesa contra os crimes tributários. E, que na verdade, além do Direito Penal se transformar, nesses casos, em instrumento de arrecadação de impostos pelo Estado, também estaria sendo utilizado como ameaça ao contribuinte. Isto porque, ou o contribuinte abria mão de impugnar o lançamento, e pagava o que lhe era imputado como sendo devido, ou impugnava a exigência, e se via a enfrentar todas as etapas de uma ação penal, que sabemos ser nada fácil e agradável. ${ }^{77}$

De maneira a amenizar a preocupação do Min. Nelson Jobim o Min. Joaquim Babosa trouxe à discussão o argumento de que o parágrafo $2^{\circ}$ do artigo $9^{\circ}$ da Lei $10.684 / 2003^{78}$ havia estendido o momento para pagar o tributo. Assim ficaria extinta a punibilidade do agente a qualquer momento que se efetuasse o pagamento.

\footnotetext{
${ }^{77}$ Para Luiz Flavio Gomes poderia haver o pagamento a posteriori do tributo se comprovado que a época, antes da denúncia, o mesmo fosse inexigível em decorrência de recurso administrativo pendente. (GOMES, Luiz Flavio. O prévio exaurimento da via administrativa nos crimes previdenciários ou tributários e a questão da suspensão do processo e da prescrição. In: BONATO, Gilson. Direito penal e direito processual penal: uma visão garantista. Rio de Janeiro: Lumen Juris, 2001.p. 154)

${ }^{78}$ Art. $9^{\circ}$ É suspensa a pretensão punitiva do Estado, referente aos crimes previstos nos arts. $1^{\circ} \mathrm{e} 2^{\circ} \mathrm{da}$ Lei $\mathrm{n}^{\circ} 8.137$, de 27 de dezembro de 1990, e nos arts. 168A e 337A do Decreto-Lei $\mathrm{n}^{\circ} 2.848$, de 7 de dezembro de 1940 - Código Penal, durante o período em que a pessoa jurídica relacionada com o agente dos aludidos crimes estiver incluída no regime de parcelamento.

$\S 2^{\circ}$ Extingue-se a punibilidade dos crimes referidos neste artigo quando a pessoa jurídica relacionada com o agente efetuar o pagamento integral dos débitos oriundos de tributos e contribuições sociais, inclusive acessórios.
} 
Logo, o contribuinte não precisaria se preocupar em abrir mão de sua defesa para se utilizar desse beneficio, pois este não teria precluido com o recebimento da denúncia. De qualquer maneira, ainda haveria o constrangimento do contribuinte de passar por uma persecução penal, antes de encerrada a esfera administrativa, caso continuasse a permitir o início da mesma, sem antes exaurir a esfera administrativa. ${ }^{79}$

\subsection{5 - Prescrição da pretensão punitiva}

No final da parte dispositiva do HC 81611 consta que a prescrição pelos crimes fiscais deve ser suspensa enquanto durar, por iniciativa do contribuinte, o processo administrativo de lançamento definitivo do débito. Por ser uma questão de alta relevância, também se faz mister apresentar aqui, a discussão em torno do tema.

Iniciado o debate acerca da prescrição, o Min. Pertence, posicionou-se no sentido de que enquanto durar o processo administrativo fiscal por iniciativa do contribuinte, o mesmo aceitaria o decorrente empecilho à instauração do processo penal, e dessa maneira, a prescrição da pretensão punitiva teria seu curso suspenso.

Para fortalecer o seu posicionamento, Pertence utilizou-se de analogia nos casos de suspensão da prescrição na hipótese em que a imunidade formal

\footnotetext{
${ }^{79}$ Nessa linha de pensamento, entende Gustavo Henrique de Souza e Silva, que a previsão de extinção da punibilidade pelo pagamento consiste numa inegável oportunidade de defesa para os acusados de cometerem crimes tributários. E que, estariam sendo violados inúmeros princípios constitucionais, como a ampla defesa, quando permitida a deflagração da ação penal, antes de constituído definitivamente o crédito tributário, pois o sujeito estaria com sua defesa mitigada, por estar impedido de pagar o que entende efetivamente devido, nos casos de provimento parcial da impugnação do lançamento, já que não há o quantum devido definitivamente. (SILVA, Gustavo Henrique de Souza e. Op. cit. p. 120)
} 
parlamentar impedisse o processo penal ${ }^{80}$, como se pode observar em seu voto condutor no Inq. 457-QO, de 10.02.93; e também nos casos em que houver a necessidade de autorização da Assembléia Legislativa para a instauração, no STJ, de processo penal contra Governador de Estado, como consignado na ementa - RTJ 158/280 ${ }^{81}$.

Por outro turno, o Min. Joaquim Babosa discordou do entendimento exposto pelo ilustre Relator, por entender que não havendo pretensão penal antes do lançamento definitivo, não haveria como suspender o prazo prescricional, na medida em que sequer existira a possibilidade de ocorrência da prescrição.

Desta forma, imputa ao Min. Sepúlveda Pertence uma confusão: tentar conciliar os conceitos de condição objetiva de punibilidade com o de prescrição. Alega que o mesmo criou uma situação "dogmaticamente incoerente". Isto porque, no âmbito de condições objetivas de punibilidade, embora consumado o delito, o fato ainda não seria punível, de forma que não se poderia falar em pretensão penal, não sendo possível o oferecimento de denúncia. E nesses casos, só com o evento superveniente é que surgiria a pretensão punitiva, e conseqüentemente, iniciar-se-ia o prazo prescricional, como ocorre nos crimes antefalimentares, nos quais o prazo começa a correr da data da constituição do estado falimentar.

Assim, concluiu o ilustre Ministro que a pretensão punitiva e a contagem do prazo prescricional só teriam início com a ocorrência do fato punível.

\footnotetext{
${ }^{80} \mathrm{Na}$ hipótese de crime praticado contra parlamentar federal, se a respectiva Casa não concedesse licença para que o deputado ou senador fosse processado, a prescrição do ius puniendi ficaria suspensa. Ocorre que o dispositivo do parágrafo $2^{\circ}$ do artigo 53 da $\mathrm{CF}$, onde se encontrava consagrado tal preceito, foi revogado pela Emenda Constitucional 35/2001.

81 "II - A necessidade da autorização previa da Assembléia Legislativa não traz o risco, quando negada, de propiciar a impunidade dos delitos contra Governadores: a denegação traduz simples obstáculo temporário ao curso de ação penal, que implica, enquanto durar, a suspensão do fluxo prescricional."
} 
Cesar Peluso, que era adepto da tese do elemento normativo do tipo, não teve muita dificuldade em expor sua opinião acerca da prescrição, por entender que segundo o artigo 111 , I do Código Penal ${ }^{82}$, a prescrição só começaria a correr da data da consumação do crime, no caso, quando estivessem configurados todos os elementos do tipo.

Outro que não se opôs a questão da prescrição foi o Min. Marco Aurélio, entendendo que não caberia, o argumento "ad terrorem" da impunidade, pois não poderia se falar em prescrição, sem o nascimento da ação penal, por ausência de justa causa pra sua propositura.

O Min. Carlos Velloso seguiu linha de raciocínio parecida com as tomadas pelos Ministros Cesar Peluso, e Marco Aurélio, por entender que a prescrição rege-se pelo princípio actio nata, ou seja, se o direito de ação ainda não nasceu, não há que se falar em prescrição. E no caso, a ação só nasceria com a realização do lançamento fiscal, com a constituição definitiva do crédito tributário.

Ao final da discussão ficou consignado entre os Ministros que o Min. Sepúlveda Pertence havia se equivocado, quando, em seu voto, disse sobre a suspensão da prescrição com base no artigo 116 do $\mathrm{CP}^{83}$, pois, na verdade, se trata de causa impeditiva da prescrição. E dessa maneira, ficou acordado que constaria no acórdão que não teria curso a prescrição. Ocorre que não foi isso que aconteceu, estando estampado no acórdão, que a prescrição estaria suspensa.

\footnotetext{
${ }^{82}$ Art. 111 - A prescrição, antes de transitar em julgado a sentença final, começa a correr: I - do dia em que o crime se consumou;

${ }^{83}$ Art. 116 - Antes de passar em julgado a sentença final, a prescrição não corre: I - enquanto não resolvida, em outro processo, questão de que dependa o reconhecimento da existência do crime; II enquanto o agente cumpre pena no estrangeiro.
} 


\section{2 - Súmula Vinculante no 24 - STF}

A decisão obtida nos autos do HC 81.611- DF serviu de espelho para inúmeros casos semelhantes que surgiram acerca da necessidade do esgotamento da esfera administrativa para a representação fiscal para fins penais. Nossos tribunais, tanto inferiores, quanto superiores, seguiram o entendimento adotado pela Corte Maior, no julgamento daquele habeas corpus, passando a matéria a ser vista de maneira uniforme.

A quantidade de julgados semelhantes foi de uma expressão tão forte, que o Supremo Tribunal Federal decidiu sumular a matéria, para que o entendimento se tornasse definitivo, e que havendo posicionamento contrário, o mesmo fosse rechaçado de plano, com o intuito de evitar o constrangimento de chegar em última instância um caso que poderia ser resolvido de imediato.

Assim, o Excelso Pretório editou, em 02.12.2009, a Súmula Vinculante $\mathrm{n}^{\circ}$ 24, assim ementada: "Não se tipifica crime material contra a ordem tributária, previsto no art. $1^{\circ}$, incisos I a IV, da Lei n. 8137/90, antes do lançamento definitivo do tributo."

Destarte, serão analisados os precedentes e os motivos da edição da presente Súmula Vinculante, para entendermos o porquê da pacificação do entendimento.

\subsection{1 - Análise dos precedentes}

Sem sombra de dúvida, o precedente mais importante para que se pacificasse o entendimento sumulado no ementário, foi o julgamento do $\mathrm{HC}$ 
81.611 - DF, mas como já foi feita analise detalhado do caso, passaremos a explanar o conteúdo abordado nos outros.

O posicionamento tomado no leading case supra mencionado, antes mesmo de publicado, já se repercutia influenciando em outros julgados que versavam sobre a mesma matéria no Supremo. Isto porque, constata-se no julgamento do HC 85.428-1 - MA ${ }^{84}$, o entendimento adotado daquela Corte.

No presente caso, os pacientes eram sócios de certa empresa que, supostamente, havia sonegado o tributo de Imposto de Renda de Pessoa Jurídica, e seus respectivos acessórios. Contudo, constava nos autos a pendência de recurso no Conselho dos Contribuintes do Ministério da Fazenda.

O Superior Tribunal de Justiça denegou a ordem do primeiro habeas corpus, entendendo que no presente caso a decisão do procedimento fiscal, em princípio, não comprometia a análise judicial, pois as condutas objetos da ação penal poderiam ser definidas em tipos diversos. Podendo a apuração da fraude, no caso o uso de notas calçadas, ser verificada pelo conjunto probatório específico, sem precisar aguardar a possibilidade de ter havido sonegação do tributo.

Ocorre que, o Supremo manteve a linha do HC 81.611, para entender que o crime somente se consumaria com o lançamento definitivo, e, havendo a

84 “EMENTA: CRIME CONTRA A ORDEM TRIBUTÁRIA. SONEGAÇÃO (ART. 1o, II E III DA LEI No 8.137/1990). NÃO ESGOTAMENTO DA VIA ADMINISTRATIVA. RECURSOS PENDENTES DE APRECIAÇÃO. AUSÊNCIA DE JUSTA CAUSA PARA A AÇÃO PENAL. ANULAÇÃO DO PROCESSO PENAL DESDE A DENÚNCIA. ORDEM CONCEDIDA. 1. A jurisprudência desta Corte já se firmou no sentido de que, quando se trata de crime contra a ordem tributária, não há causa que justifique a ação penal antes do exaurimento da esfera administrativa (HC no 81.611-DF, Rel. Min. Sepúlveda Pertence, DJ de 13.05.2005). 2. Também é entendimento pacífico deste Tribunal que, enquanto durar o processo administrativo, não há cogitar do início do curso do lapso prescricional, visto que ainda não se consumou o delito (HC no 83.414-RS, Rel. Min. Joaquim Barbosa, DJ de 23.04.2004; AI no 419.578-SP, Rel. Min. Sepúlveda Pertence, DJ de 27.08.2004; e HC no 84.092-CE, Rel. Min. Celso de Mello, DJ de 03.12.2004)." (STF, HC 85.428-1, Rel. Ministro Gilmar Mendes, Brasília, 17 mai. de 2005.) 
pendência de recursos, não poderia se falar em crime, sequer se cogitar de justa causa para a persecução penal, rechaçando a tese do STJ.

Dessa maneira, concedeu a ordem para anular a ação penal desde o recebimento da denúncia, não obstando a possibilidade de haver nova, caso não fosse julgado procedente o recurso na esfera fiscal. Insta frisar, que o STF também entendeu que não teria início o curso do lapso prescricional, por não ter se consumado o crime.

Por outro turno, curiosidade importante ocorreu no julgamento do $\mathrm{HC}$ 86.120-2 $2^{85}$ - SP, de relatoria do Min. Sepúlveda Pertence, que versava sobre a questão do exaurimento da esfera administrativa fiscal, para a possibilidade de representação fiscal. Ocorre que nesse julgado, ao invés de se tratar de ação penal, a impetração tinha como objetivo trancar inquérito policial.

A autoridade coatora, no caso o Superior Tribunal de Justiça, posicionou-se no sentido de que o entendimento firmado pelo Supremo só se aplicaria aos casos de ação penal, não atingindo os inquéritos, por entender que esses eram meras peças informativas. E dessa maneira, o STJ entendeu que era insubsistente a alegação de que, na pendência do processo administrativo para apurar eventual sonegação fiscal, não poderia ser instaurado o inquérito policial para a prática de algum delito, e assim denegou a ordem para trancamento do inquérito.

85 "EMENTA: I. Habeas corpus: admissibilidade: trancamento de inquérito policial. Se se trata de processo penal ou mesmo de inquérito policial, a jurisprudência do STF admite o Habeas corpus, dado que de um ou outro possa advir condenação à pena privativa de liberdade, ainda que não iminente, cuja aplicação poderia ser viciada pela ilegalidade contra a qual se volta a impetração da ordem. II. Crime material contra a ordem tributária (L. 8.137/90, art. $1^{\circ}$ ): lançamento do tributo pendente de decisão definitiva do processo administrativo: falta de justa causa para a ação penal, suspenso, porém, o curso da prescrição enquanto obstada a sua propositura pela falta do lançamento definitivo: precedente (HC 81.611, Pleno, 10.12.2003, Pertence, Inf.STF 333)." (STF, HC 86.120-2, Rel. Ministro Sepúlveda Pertence, Brasília, 09 ago. de 2005.) 
Ocorre que, o STF, por unanimidade, seguindo o voto do Ministro Relator divergiu do entendimento do STJ, afirmando que a cristalização dos julgados anteriores, inclusive o leading case do HC 81.611-DF, também seria aplicada a espécie. E assim, se fortificou a tese de que antes do lançamento definitivo, o fato seria atípico, patente de constrangimento ilegal na instauração do inquérito policial, que possui o habeas corpus como remédio para sanar essa ilegalidade.

Pedro Antonio de Oliveira Machado e Douglas Fischer entendem que é preciso cautela ao aplicar-se uma ficção jurídica - transferir ou condicionar a consumação de um delito à realização de um ato formal administrativo - nos crimes contra a ordem tributária. Pois, segundo eles, estariam sendo criados perigosos precedentes ao se concluir que, como a consumação do delito somente se dá com o lançamento definitivo (ficção jurídica), a própria investigação criminal e o inquérito policial não poderiam ser iniciados enquanto não verificada esta condição. ${ }^{86}$

Outro caso que repercutiu como precedente para o presente estudo foi o HC 83.353 - RJ, em que novamente havia a discussão sobre a pendência do processo administrativo, entendendo-se que descaberia adentrar o campo penal quer considerada a ação penal propriamente dita, quer o inquérito policial. ${ }^{87}$

No caso em tela, os impetrantes, além de alegarem que a denúncia seria genérica, ou seja, que não havia individualizado as condutas dos pacientes, a deflagração da ação penal configurava-se como um constrangimento ilegal, pois ainda havia a pendência de processo administrativo.

\footnotetext{
${ }^{86}$ MACHADO, Pedro Antonio de Oliveira. \& FISCHER, Douglas. O inquérito policial ou a investigação criminal nos crimes contra a ordem tributária. Boletim dos Procuradores da Republica, ano IX, n ${ }^{\text {o } 74, ~ p .13-15, ~ m a i o ~ 2007 . ~ p . ~} 15$

87 “CRIME TRIBUTÁRIO - PENDÊNCIA DE PROCESSO ADMINISTRATIVO. Pendente processo administrativo, descabe adentrar o campo penal quer considerada a ação propriamente dita, quer inquérito policial - inteligência do artigo 34 da Lei no 9.249/95. Precedente: Habeas Corpus n ${ }^{\circ} 81.611$ 8/DF, relator ministro Sepúlveda Pertence, julgado no Plenário, com acórdão publicado no Diário da Justiça de 13 de maio de 2005" (STF, HC 83.353-5, Rel. Ministro Marco Aurélio, Brasília, 13 set. de 2005.)
} 
Ocorre que, no presente caso, havia certa peculiaridade, que o diferenciava dos outros precedentes analisados. Nele, tanto colacionado aos autos, quanto nos votos dos Ministros, restou comprovado o pagamento do imposto supostamente devido, e dessa maneira, estaria configurada a extinção da punibilidade pelo pagamento.

Nessa linha, o STF, por unanimidade, julgou procedente o presente writ, para trancar a ação penal, com base na inteligência do artigo 34 da Lei 9249/95. E, mesmo se assim não fosse o processo penal não poderia continuar por faltar justa causa, já que pendia de recurso na esfera administrativa.

Mais um habeas corpus que foi julgado de plano, sem meras dificuldades foi o $\mathrm{HC}$ 85.463-0 - $\mathrm{RJ}^{88}$, por aplicar-se ao mesmo o posicionamento já exposto pelo STF, sobre o lançamento definitivo só se concretizar com a decisão final irrecorrível da esfera administrativa.

Casos como este chegavam ao Supremo, pois o STJ persistia em adotar teses destoantes da Corte Maior. No caso em pauta, o STJ argumentava que a existência do procedimento administrativo não tinha o condão, de por si só, obstar formalmente uma apuração criminal, e que não havia como comprovar cabalmente que os débitos parcelados eram os mesmos expostos na denúncia.

Sem dar muitos detalhes, a primeira Turma do STF, decidiu, por unanimidade, conceder a ordem com base em todas as discussões já travadas até aquela data e que já se configurava pacífica por aquela Corte.

88 “EMENTA: HABEAS CORPUS. CRIME CONTRA A ORDEM TRIBUTÁRIA. ALEGAÇÃO DE QUE NÃO HÁ JUSTA CAUSA PARA A AÇÃO PENAL ENQUANTO O LANÇAMENTO DO TRIBUTO ESTIVER PENDENTE DE DECISÃO DEFINITIVA NO PROCESSO ADMINISTRATIVO TRIBUTÁRIO. O Plenário do Supremo Tribunal Federal, no julgamento do HC 86611, fixou o entendimento de que para o oferecimento da denúncia por crime contra a ordem tributária é imprescindível o exaurimento da via administrativa. Habeas corpus concedido para trancar a ação penal, sem prejuízo do oferecimento de nova denúncia após exaurida a esfera administrativa. Razão pela qual fica suspenso o curso do prazo prescricional." (STF, HC 85.463-0, Rel. Ministro Carlos Britto, Brasília, 07 jun. de 2005.) 
Por fim, o último Habeas Corpus em comento, é o HC 85.185 - SP. ${ }^{89}$ Nesse julgado, de início, houve uma longa discussão acerca da aplicação da Súmula $691^{90}$, isto é, da possibilidade do Supremo Tribunal Federal conhecer de $\mathrm{HC}$ impetrado contra decisão de relator que indeferiu liminar de $\mathrm{HC}$ impetrado em Tribunal Superior.

Como para o presente trabalho tal tema não possui muita relevância, suficiente dizer que depois de um extenso debate, o Supremo decidiu não envolver a Súmula em questão, nem alterá-la, valendo-se de outra solução: a concessão de Habeas Corpus de ofício, no moldes do artigo 654, § 2º do CPP, que assim dispõe:

“Art. 654. O habeas corpus poderá ser impetrado por qualquer pessoa, em seu favor ou de outrem, bem como pelo Ministério Público.

$\S 2^{\underline{0}}$ Os juízes e os tribunais têm competência para expedir de ofício ordem de habeas corpus, quando no curso de processo verificarem que alguém sofre ou está na iminência de sofrer coação ilegal."

Assim, o Excelso Pretório decidiu conceder o habeas corpus de oficio, por entender que no caso em questão, ainda havia recurso pendente na esfera administrativa, não sendo possível a ação penal continuar por seu curso

89 “EMENTAS: 1. COMPETÊNCIA CRIMINAL. Habeas corpus. Impetração contra decisão de ministro relator do Superior Tribunal de Justiça. Indeferimento de liminar em habeas corpus. Rejeição de proposta de cancelamento da súmula 691 do Supremo. Conhecimento admitido no caso, com atenuação do alcance do enunciado da súmula. O enunciado da súmula 691 do Supremo não o impede de, tal seja a hipótese, conhecer de habeas corpus contra decisão do relator que, em habeas corpus requerido ao Superior Tribunal de Justiça, indefere liminar. 2. AÇÃO PENAL. Tributo. Crime contra a ordem tributária, ou crime tributário. Procedimento administrativo não encerrado. Pendência de recurso administrativo. Lançamento não definitivo. Delito ainda não tipificado. Jurisprudência assentada do Supremo. Constrangimento ilegal caracterizado. Extinção do processo. HC concedido de ofício para esse fim. Pedido prejudicado. Crime contra a ordem tributária não se tipifica antes do lançamento definitivo de tributo devido." (STF, HC 85.185-1, Rel. Ministro Cezar Peluso, Brasília, 10 de ago. de 2005.)

${ }^{90}$ Súmula 691, do STF: "NÃO COMPETE AO SUPREMO TRIBUNAL FEDERAL CONHECER DE "HABEAS CORPUS" IMPETRADO CONTRA DECISÃO DO RELATOR QUE, EM "HABEAS CORPUS" REQUERIDO A TRIBUNAL SUPERIOR, INDEFERE A LIMINAR." 
normal, devendo a mesma ser trancada, não ficando impedida nova denúncia caso os recursos não fossem julgados procedentes. Não houve um grande debate acerca do mérito, apenas a citação de inúmeros precedentes, inclusive de alguns, por nós aqui comentados.

\subsection{2 - Exposição de motivos}

Diante dos julgados examinados, os Ministros do STF, em sessão plenária do dia 02/12/2009, reuniram-se para debater a proposta de edição da Súmula Vinculante $\mathrm{n}^{\mathrm{o}} 24$, visto que os entendimentos consagrados naqueles precedentes, já tinham se tornados uniformes e prontos para serem cristalizados no teor de uma Súmula.

O Min. Cesar Peluso, em sua explicação da proposta, deixou claro que após reiterados julgamentos, em havendo dúvida sobre a existência do crédito tributário, evidentemente, também haveria dúvida sobre a existência de elemento normativo do tipo, tese pelo próprio defendida. E para ele, a jurisprudência não tinha dúvida quanto a essa conclusão. A divergência seria quanto ao fundamento, em que uns entenderiam ser uma questão prejudicial, outros condição objetiva de punibilidade, e outros, como elemento normativo do tipo.

Ocorre que, o jurista também entendia que este não era o objeto da Súmula, mas sim, a conclusão da Corte de que não haveria possibilidade de exercício de ação penal antes da apuração da existência certa do crédito tributário.

Para o Min. Dias Toffoli, a proposta da Súmula se enquadrou muito bem a intenção do legislador, no sentido de estabelecer uma política de arrecadação, sem abrir mão do tipo penal. 
Para dar embasamento ao seu raciocínio, o Min. citou o fato de inúmeras Leis de parcelamento servirem para essa política de arrecadação, como o artigo $9^{\circ}$ da Lei $10.684 / 2003$, que dispõe sobre a suspensão da pretensão punitiva do Estado, quando a pessoa jurídica estiver incluída no regime do parcelamento. E concluiu que o tipo penal incidirá no momento em que o contribuinte olvidar do seu pagamento, cabendo aos Ministros abraçar ou não seus pontos de vistas pessoais - todavia era o que constava da Lei.

Por oportuno, o Min. Carlo Ayres Britto, expôs, após refletir por muito tempo, que seria preciso deixar que o processo administrativo tributário chegasse ao seu término, uma vez que é um direito do contribuinte levar os meios e recursos de que fala o inciso LVX do artigo $5^{\circ}$ da CF, sob pena de se transformar uma ampla defesa do procedimento fiscal, em uma "curta defesa".

Por outro turno, o assunto que teve a maior repercussão no debate foi a questão da prescrição.

Os Ministros Joaquim Barbosa, Ellen Gracie e Marco Aurélio foram contra a edição da Súmula, pois queriam que constasse da mesma a questão da prescrição. Isto porque, como em todos os precedentes julgados, sempre foi discutida essa matéria, não poderia a Súmula se omitir com relação a esse ponto.

Para Peluso, a Súmula não mencionava nada sobre prescrição, vez que a mesma não foi elaborada para negar, nem afirmar a prescrição, já que era uma matéria que estava em aberto, e que, portanto, poderia ser rediscutida.

No calor da discussão, o Min. Joaquim Barbosa defendia a posição de que deveria constar na Súmula, a questão da prescrição, pois esta constava do julgamento do leading case, bem como de inúmeros julgados. Nesse momento o Min. Ricardo Lewandowski sugeriu a possibilidade de a prescrição fazer 
parte de outra Súmula, dando margem ao Min. Joaquim Barbosa concluir que a matéria estaria sendo sumulada pela metade.

Seguindo a linha do Min. Joaquim Barbosa, a Min. Ellen Gracie entendeu que se não fosse constar a prescrição, era porque a matéria ainda não estava pacificada, e que se deveria aguardar mais, para que todas as dúvidas, e obscuridades fossem sanadas, para só então, ser sumulado verbete sobre a matéria em questão.

Sem nos aprofundarmos muito quanto à prescrição, pois a mesma será analisada no próximo Capítulo, concluímos que o motivo para edição do verbete da Súmula Vinculante $\mathrm{n}^{\circ} 24$ se deu porque, independente da natureza jurídica que se atribua ao lançamento definitivo do tributo, não poderá haver persecução penal nos crimes contra a ordem tributária, tipificados no artigo $1^{\circ}$, I à IV, sem antes exaurida a esfera administrativa. 


\section{4 - ASPECTOS ATUAIS ACERCA DA MATÉRIA PÓS HC 81.611- DF.}

Não obstante o que foi debatido até agora, necessário trazer a este trabalho as questões que não foram abordadas nos julgamentos dos precedentes invocados, ou que, ainda quando abordadas, não tiveram uma definição, deixando pontos da matéria em aberto.

\section{1 - Prescrição}

Como exposto na analise do HC 81.611-DF, e na exposição de motivos que deram origem a Súmula Vinculante $n^{\circ} 24$, no que diz respeito à prescrição, apesar de ter sido constantemente invocada, não se chegou a um consenso, ficando a presente matéria em aberto, gerando possíveis dúvidas e indagações quanto à mesma na aplicação pelos tribunais do país.

Dessa maneira, até onde entendemos, ficou consignado que a prescrição pelos crimes fiscais deveria ser suspensa enquanto durar, por iniciativa do contribuinte, o processo administrativo de lançamento definitivo do débito.

Logo, se por tanto tempo foi debatida essa questão, porque não deixar tal assertiva expressa no verbete editado pelo Supremo?

Para responder a essa pergunta, o melhor entendimento foi aquele exposto por Gustavo Henrique de Souza e Silva, pois segundo o autor, esse raciocínio não poderia estar dissociado da discussão sobre em qual categoria a decisão administrativa de lançamento definitivo estaria enquadrada na estrutura do delito, se na categoria de condição objetiva de punibilidade, ou se elemento normativo do tipo, ou se questão prejudicial heterogênea. ${ }^{91}$ Ressalve-se que tal

${ }^{91}$ SILVA, Gustavo Henrique de Souza e. Op. cit. p. 122 
discussão também não chegou a um consenso quando do julgamento do leading case, bem como da edição da Súmula Vinculante.

Isto porque, entendendo ser uma condição objetiva de punibilidade, como sugerido pelo Min. Sepúlveda Pertence, não seria possível sustentar a suspensão do prazo prescricional pela simples razão de que não haveria Lei expressa neste sentido.

Quando os Ministros trazem a discussão acerca da aplicação do artigo 116 do Código Penal ${ }^{92}$, primeiramente é necessário mencionar que não se trata de causas de suspensão da prescrição, e sim de causas impeditivas, conforme a mesma expressão utilizada pelo $\mathrm{CP}$. Segundo, que o mesmo não poderia ocorrer, pois as causas ali previstas não poderiam ser interpretadas de forma extensiva, visto que essa interpretação é vedada no direito penal em desfavor do réu.

Ademais, quando o Supremo Tribunal Federal prevê a possibilidade de “criar" essa nova modalidade de "suspensão", estaria este órgão do Judiciário legislando por conta própria, o que seria uma atitude deveras inconstitucional, e contrária a todo ordenamento jurídico, pois estaria ferindo a Lei Maior, visto que a competência para legislar sobre matéria penal, e processual é privativa da União, como decorre do artigo 22, I, da Constituição Federal:

“Art. 22. Compete privativamente à União legislar sobre:

I - direito civil, comercial, penal, processual, eleitoral, agrário, marítimo, aeronáutico, espacial e do trabalho;"

\footnotetext{
${ }^{92}$ Causas impeditivas da prescrição

Art. 116 - Antes de passar em julgado a sentença final, a prescrição não corre:

I - enquanto não resolvida, em outro processo, questão de que dependa o reconhecimento da existência do crime;

II - enquanto o agente cumpre pena no estrangeiro.

Parágrafo único - Depois de passada em julgado a sentença condenatória, a prescrição não corre durante o tempo em que o condenado está preso por outro motivo.
} 
Vale salientar que os argumentos de processos trazidos para fundamentar o raciocínio da aplicação do artigo 116 do $\mathrm{CP}$, o princípio da actio nata defendido pelo, então Ministro, Carlos Velloso em voto nos autos do HC 81.611-DF (enquanto não puder haver propositura da ação não se pode começar a contar a prescrição) - seria inaplicável, pois a prescrição penal é tema de direito penal, e não de direito processual. ${ }^{93}$

Ao contrário seria, caso a prescrição fosse de cunho processual, em que com base no artigo $3^{\circ}$ do $\mathrm{CPP}^{94}$, há a previsão de aplicação extensiva e análoga.

Por outro turno, caso se entenda que o lançamento definitivo seja elemento normativo do tipo, fato é que o prazo prescricional não ficaria suspenso, pois sequer terá tido o seu termo a quo, que no caso seria a consumação do delito, só ocorrendo com o fim do procedimento administrativo e com o lançamento definitivo.

Nessa linha, aduz Diogo Malan que a afirmação do Supremo Tribunal Federal estaria equivocada, no sentido de haver a suspensão do prazo prescricional da pretensão estatal punitiva durante a tramitação do processo administrativo fiscal. ${ }^{95}$

Isto porque, o termo para iniciar a fluência do prazo prescricional penal seria o momento em que o crime se consumasse, em outras palavras, quando fossem reunidos todos os elementos necessários de sua definição legal como disposto na combinação do artigo 14, I, e do artigo 111, I, ambos do Código Penal, expostos abaixo:

\footnotetext{
${ }^{93}$ SILVA, Gustavo Henrique de Souza e. Op. cit. p. 122

${ }^{94}$ Art. $3^{\text {o }}$ A lei processual penal admitirá interpretação extensiva e aplicação analógica, bem como o suplemento dos princípios gerais de direito.

${ }^{95}$ MALAN, Diogo. Op. cit. p. 463
} 
"Art. 14 - Diz-se o crime:

I - consumado, quando nele se reúnem todos os elementos de sua definição legal"

“Art. 111 - A prescrição, antes de transitar em julgado a sentença final, começa a correr:

I - do dia em que o crime se consumou;"

Dessa maneira, fácil concluir que o prazo prescricional dos crimes contra a ordem tributária só começaria a correr no ato do lançamento definitivo do crédito tributário, que segundo, novamente, Diogo Malan, seria elemento normativo do tipo penal em estudo, não se permitindo a suspensão antes disso, pois sequer o prazo haveria começado. ${ }^{96}$

Em sentido contrário, Janaina Paschoal e Jorge Coutinho Paschoal entendem que a decisão definitiva na esfera administrativa estaria sim, relacionada à tipicidade, não sob o enfoque da consumação, mas sob o da materialidade. ${ }^{97}$

Isto porque, os autores fazem um paralelo com o crime de homicídio, em que alguém dispara uma arma contra outrem, vindo o último a morrer, sendo o corpo submetido a um exame necroscópico um mês depois. Na hipótese, a consumação teria ocorrido no dia do disparo, e a constatação delitiva, só depois, com o resultado do exame. ${ }^{98}$

Assim, para os autores, voltando à questão fiscal, a decisão definitiva do lançamento, não alteraria o momento da consumação do crime, mas serviria

\footnotetext{
${ }^{96}$ Ibid. p. 463

97 PASCHOAL, Janaina Conceição; PASCHOAL. \& Jorge Coutinho. A constituição do crédito tributário: a consumação do crime tributário e a extinção da punibilidade pela prescrição. Boletim IBCCRIM, São Paulo, ano 16, n. 194, p. 2-3, jan. 2009. p. 2

${ }^{98}$ Ibid. p. 2
} 
para atestar a materialidade. E, o entendimento contrário geraria questões deveras teratológicas. ${ }^{99}$

Tais autores ponderam ser compreensível o esforço de evitar a impunidade, transportando a consumação do crime para o momento da decisão definitiva na esfera administrativa, que passaria a ser o termo inicial da prescrição. Ocorre que, os mesmos entendem que, por mais importante que seja a política criminal e/ou sua valorização acadêmica não poderiam ser colocados de lado princípios tão caros ao Direito Penal. ${ }^{100}$

Razão pela qual, até os crimes mais graves e mais atentatórios prescrevem, como no caso do homicídio exposto acima. E assim, os autores concluem que, se o reconhecimento de que a decisão administrativa definitiva está relacionada à materialidade e não à consumação do crime tributário, gera impunidade, então, que se legisle, prevendo expressamente a suspensão do curso do prazo prescricional, que deve começar com a consumação definitiva, muito anterior à constatação da materialidade. O que não se poderia admitir seria qualquer tipo de interpretação analógica ou extensiva que prejudicasse o imputado, deixando que o mesmo conviva com a possibilidade de em qualquer fase de sua vida ser perseguido criminalmente, e até condenado por não estar amparado pelo instituto da prescrição como deveria realmente ser. ${ }^{101}$

Para quem defende que a análise da matéria é uma questão prejudicial, a suspensão do processo nos termos do artigo 93 do Código de Processo Penal, também suspende o curso da prescrição.

\footnotetext{
${ }^{99}$ Em sua obra, os autores, exemplificam essas situações como no caso de um contribuinte que durante muitos anos estava respondendo um processo criminal, por suposta omissão de informações de rendimentos, e viu toda a persecução ser anulado, por um habeas corpus de oficio, pois o feito fora iniciado antes da decisão final fiscal. E ironizam os autores, ao dizerem que como ressarcimento pelo constrangimento ilegal sofrido, o mesmo cidadão viu-se novamente denunciado, pelos mesmos fatos, pois nesse entendimento a consunção do delito só teria ocorrido com a decisão definitiva, e que somente então teria início o curso do prazo prescricional.

100 PASCHOAL, Janaina Conceição; \& PASCHOAL. Jorge Coutinho. Op.cit. p. 3

${ }^{101}$ Ibid. p. 3
} 
Como adeptos desta linha, podemos citar o Ministro Joaquim Barbosa, que em seu voto do HC 81.611, deixou clara sua posição, sendo sua solução para a até então polêmica questão da prescrição, como também já defendeu o professor Luiz Flavio Gomes ${ }^{102}$, que quando pudesse aplicar o artigo 93 do CPP, também seria aplicado o artigo 116, I do CP.

Depois de abordar cada posicionamento sobre a prescrição, entendemos ser realmente necessário pacificar a natureza jurídica acerca da matéria: condição objetiva de punibilidade, elemento normativo do tipo, ou questão prejudicial.

O STF, ao decidir o caso do HC 81.611, e editar a Súmula Vinculante $\mathrm{n}^{\circ}$ 24, no sentido de que não poderá haver a persecução penal antes de exaurida a esfera administrativa, sem, contudo definir a natureza jurídica da representação fiscal acabou por fragilizar o instituto da prescrição, que como vimos, depende dessa definição para melhor se aplicar.

Por esse turno, vimos que a edição desse verbete foi prematura, nesse ponto, já que deveria ser feito um estudo aprofundado por parte dos Ministros do Supremo para considerar pacífica uma matéria de suma importância como essa. Mas como isso não foi feito, só poderemos refletir acerca da melhor solução para resolver esse deslinde.

Entendemos, primeiramente, que o STF, deveria voltar a discutir essa matéria em seu plenário, para afinal decidir sobre a natureza jurídica do lançamento definitivo do crédito tributário, pois não é concebível que fique em aberto, deixando margem a dúvidas, em questões de suma relevância como a da prescrição.

Feito isto, caso, realmente, entenda ser uma condição objetiva de punibilidade, o Supremo deveria, nos moldes do artigo 61 da CF, ter a iniciativa de criar um projeto Lei em que fosse prevista a criação de mais uma

${ }^{102}$ GOMES, Luiz Flavio. Op. cit. 155 
causa impeditiva da prescrição, acrescentando outro inciso ao artigo 116 do $\mathrm{CP}$, para dessa maneira, rechaçar a tese daqueles que defendem que o mesmo artigo não poderia ser aplicado por falta de previsão legal, e de interpretação extensiva.

Por outro turno, se ficar definido como elemento normativo do tipo, a prescrição realmente só poderá correr quando consumado o crime, ou seja, com a decisão definitiva do lançamento. Nesse caso, deveria extirpar o entendimento da suspensão da prescrição, vez que ainda não haveria início da contagem, e isto deveria constar em algum verbete de Súmula do STF.

Assim, a questão da prescrição estaria resolvida de plano.

\section{2 - Aplicabilidade da Súmula a outros casos}

Ultrapassada a questão da prescrição, um ponto de extrema relevância que não foi abordado no momento da criação da Súmula, foi a possibilidade de aplicação dos efeitos do mesmo verbete a outros casos que se assemelham aos delitos tipificados no artigo $1^{\circ}$, I à IV, da Lei 8137/90, quais sejam: o artigo $2^{\circ}$ do mesmo diploma legal; aos crimes de apropriação indébita previdenciários; e aos crimes de descaminho.

Assim, abordaremos, separadamente, cada um deles, expondo os motivos para a possibilidade de aplicação do dispositivo vinculante.

\subsection{1 - Artigo $2^{\circ}$ da Lei 8137/90}

O artigo $2^{\circ}$ da Lei 8137/90, quando em seu caput expõe "constitui crime da mesma natureza", segundo uma corrente doutrinária, está se referindo à 
natureza de crime contra a ordem tributária, no caso, crimes formais, de mera conduta; Por outro lado, há quem alegue que "constitui crime da mesma natureza" esteja se referindo o artigo quanto ao resultado, ou seja, todos seriam crimes materiais.

O STF na edição do verbete da Súmula em análise entendeu que somente os delitos do artigo $1^{\circ}$ seriam materiais, tanto que constou da seguinte maneira: "Não se tipifica crime material contra a ordem tributária, previsto no art. $1^{\circ}$, incisos I a IV, da Lei n. 8137/90...”

Todavia, o artigo 83 da Lei 9430/96, já analisado, abrangia os delitos tanto do artigo $1^{\circ}$, quanto do artigo $2^{\circ}$, dizendo que, em ambos, as autoridades fazendárias deveriam aguardar o encerramento da esfera administrativa, para remeter o material fiscal para representação.

Dessa maneira, quando a Corte Maior editou a Súmula, mesmo com o grande avanço que ela representou, qual seja, impedir a deflagração penal antes da decisão definitiva da esfera judicial nos casos do artigo $1^{\circ}$, a mesma poderia ter ido além. Principalmente porque limitou sua aplicação para os casos dos crimes até então entendidos materiais do artigo $1^{\circ}$.

E como assevera Flávio Tudisco, essa limitação seria criticável, na medida em que se ignora que para certos casos do artigo $2^{\circ}$, como o inciso I, também deveria existir, necessariamente uma relação de pertinência entre a conduta praticada e a intenção de eximir-se do pagamento do tributo. Intenção essa que, a despeito de não ter que resultar em efetivo prejuízo ao Fisco, exige ao menos a possibilidade de isto acontecer, já que não poderia haver essa intenção, se, por exemplo, não se tratasse de um contribuinte deste mesmo tributo. ${ }^{103}$

\footnotetext{
${ }^{103}$ TUDISCO, Flávio. Controvérsias sobre o direito penal tributário. Valor Econômico. São Paulo, p. E04. 21 mai 2010.
} 
Destarte, vejamos a leitura do inciso I, do artigo $2^{\circ}$ : "I - fazer declaração falsa ou omitir declaração sobre rendas, bens ou fatos, ou empregar outra fraude, para eximir-se, total ou parcialmente, de pagamento de tributo;"

Nesse caso, novamente segundo o autor, aquele que fizer declaração falsa ou mesmo omitir declaração sobre rendas, mas que não seja contribuinte do tributo não pode, jamais, ter tido a intenção de eximir-se de seu pagamento, não para fins da aplicação da Lei 8137/90. ${ }^{104}$

Essa diferença, entre ser ou não o contribuinte do tributo, pode ter de ser decidida em sede de processo administrativo fiscal próprio, antes de eventual processo criminal. O que, pela atual leitura da Súmula Vinculante ${ }^{\circ} 24$, não seria possível, tendo em vista que a mesma se omitiu quanto a isso, podendo acarretar inúmeros prejuízos, já expostos anteriormente, como nos casos relativos ao artigo $1^{\circ}$, quando se inicia a persecução penal antes de exaurida a esfera administrativa.

Assim, fácil constatar que, também para esses casos do artigo $2^{\circ}$ da Lei 8137/90, sendo formal, ou material, a existência de eventual processo administrativo em que se discuta a exigibilidade do crédito tributário deverá obstar o processo criminal, caso a intenção do mesmo seja fundada na Lei de crimes contra a ordem tributária, e não quanto à outra conduta tipificada no Código Penal.

\subsection{2 - Crime de descaminho}

Outro caso que se assemelha a toda a controvérsia e debate sobre os crimes contra a ordem tributária é o caso do crime de descaminho. Como disposto no artigo 334 do Código Penal, a tipificação do delito em analise seria:

\footnotetext{
${ }^{104}$ Ibid. p. E04.
} 
"Art. 334 Importar ou exportar mercadoria proibida ou iludir, no todo ou em parte, o pagamento de direito ou imposto devido pela entrada, pela saída ou pelo consumo de mercadoria:

Pena - reclusão, de um a quatro anos.

$\S 1^{\circ}$ - Incorre na mesma pena quem:

a) pratica navegação de cabotagem, fora dos casos permitidos em lei;

b) pratica fato assimilado, em lei especial, a contrabando ou descaminho;

c) vende, expõe à venda, mantém em depósito ou, de qualquer forma, utiliza em proveito próprio ou alheio, no exercício de atividade comercial ou industrial, mercadoria de procedência estrangeira que introduziu clandestinamente no País ou importou fraudulentamente ou que sabe ser produto de introdução clandestina no território nacional ou de importação fraudulenta por parte de outrem;

d) adquire, recebe ou oculta, em proveito próprio ou alheio, no exercício de atividade comercial ou industrial, mercadoria de procedência estrangeira, desacompanhada de documentação legal, ou acompanhada de documentos que sabe serem falsos.

$\S 2^{\circ}$ - Equipara-se às atividades comerciais, para os efeitos deste artigo, qualquer forma de comércio irregular ou clandestino de mercadorias estrangeiras, inclusive o exercido em residências.

$\S 3^{\circ}$ - A pena aplica-se em dobro, se o crime de contrabando ou descaminho é praticado em transporte aéreo."

O primeiro ponto a ser enfrentado, para explicarmos a semelhança do crime de descaminho com os já analisados, é entendermos que, na verdade, o crime de descaminho se trata de um delito contra a ordem tributária, ou seja, podemos dizer que seria uma espécie do gênero crimes contra a ordem tributária.

Isto porque, temos que ter em mente, que quando certa mercadoria entra em nosso país, de maneira a ludibriar a fiscalização alfandegária para pagar menos imposto, ou imposto algum, neste caso, o agente estará lesando o erário público, sonegando imposto.

Nessa linha de raciocínio, foi que o STJ julgou procedente o Habeas Corpus $n^{\mathbf{o}}$ 109.205/PR, de relatoria da Min. Jane Silva, para trancar a ação penal, como exposto na ementa abaixo:

"PENAL - HABEAS CORPUS - DESCAMINHO - TRANCAMENTO DA AÇÃO PENAL - AUSÊNCIA DE PRÉVIA CONSTITUIÇÃO DO CRÉDITO TRIBUTÁRIO NA ESFERA ADMINISTRATIVA - NATUREZA TRIBUTÁRIA DO DELITO - ORDEM CONCEDIDA. 
1. Consoante recente orientação jurisprudencial do egrégio Supremo Tribunal Federal, seguida por esta Corte, eventual crime contra a ordem tributária depende, para sua caracterização, do lançamento definitivo do tributo devido pela autoridade administrativa.

2. O crime de descaminho, por também possuir natureza tributária, eis que tutela, dentre outros bens jurídicos, o erário público, deve seguir a mesma orientação, já que pressupõe a existência de um tributo que o agente logrou êxito em reduzir ou suprimir (iludir). Precedente.

3. Ordem concedida para trancar a ação penal ajuizada contra os pacientes no que tange ao delito de descaminho, suspendendo-se, também, o curso do prazo prescricional." (STJ, HC 109.205, Rel. Ministra Jane Silva, Brasília, 02 de out. de 2008.)

Na espécie, a Ministra deixou consignado em seu voto vencedor, que o bem jurídico tutelado no caso era o erário publico, tendo em vista que a conduta descrita era a de proceder a entrada, ou saída de mercadoria do país, sem o pagamento do imposto devido.

Destarte, a ilustre Ministra expõe que o artigo 334 do CP, da mesma forma que o artigo $1^{\circ}$ da Lei $8137 / 90$, pressupõe a existência de um tributo que o agente tenha logrado êxito em suprimir, ou reduzir. Além disso, a relatora faz um paralelo ao HC 81.611, dizendo que em ambos os casos, por serem os crimes ali analisados de natureza material, todas as observações do julgado do leading case poderiam ser aplicadas à espécie.

E ao concluir esse raciocínio, menciona que a Secretaria da Receita Federal editou a Portaria 655/2008 referente aos procedimentos específicos da representação fiscal para fins penais, que em seu artigo $5^{\circ}$ trata especificamente do caso do descaminho, condicionando o envio da representação fiscal apenas quando for aplicada a pena administrativa de perdimento de bens, e determinado o seu arquivamento nos caos de absolvição. ${ }^{105}$

105 Artigo 5o. A representação fiscal para fins penais relativa aos crimes de contrabando ou descaminho, definidos no art. 334 do Código Penal, será formalizada em autos separados e 
Não é outra a visão de Gustavo Henrique de Souza e Silva, que ao concordar que o delito de descaminho possuía natureza de crime material, entende que também seriam aplicadas as regras de extinção da punibilidade. ${ }^{106}$

Assim, dúvida não restaria quanto à aplicação do entendimento do HC 81.611, bem como da Sumula Vinculante 24, aos crimes de descaminho.

Ocorre que isso não constou da Súmula, e assim, uma boa maneira para solucionar esse problema, seria a proposta de revisão da Súmula - feita por aqueles mesmos entes responsáveis para propor ação direita de inconstitucionalidade, como ditames expressos do $\S 2^{\circ}$ do artigo 103-A da CF ou a edição por novo verbete por parte do Supremo para adequar o caso ao tema do presente trabalho.

\subsection{3 - Crime de apropriação indébita previdenciária}

Da mesma forma que o crime de descaminho, outro crime que poderia constar da Súmula e acabou passando despercebido, foi o crime de apropriação indébita previdenciária, tipificado no artigo 168-A do CP, que assim dispõe:

"Art. 168-A. Deixar de repassar à previdência social as contribuições recolhidas dos contribuintes, no prazo e forma legal ou convencional:

Pena - reclusão, de 2 (dois) a 5 (cinco) anos, e multa.

$\S 1^{\circ}$ Nas mesmas penas incorre quem deixar de:

I - recolher, no prazo legal, contribuição ou outra importância destinada à previdência social que tenha sido descontada de pagamento efetuado a segurados, a terceiros ou arrecadada do público;

protocolizada na mesma data da lavratura do auto de infração, devendo permanecer na unidade da RFB de lavratura até o final do prazo para impugnação.

$\S 1^{\circ}$. Se for aplicada a pena de perdimento de bens, inclusive na hipótese de conversão em multa equivalente ao valor aduaneiro da mercadoria que não seja localizada ou que tenha sido consumida, a representação de que trata o caput deverá ser encaminhada pela autoridade julgadora de instância única ao órgão do Ministério Público Federal que for competente para promover a ação penal, no prazo máximo de 10 (dez) dias, anexando-se cópia da decisão.

$\S 2^{\circ}$. Não aplicada a pena de perdimento, a representação fiscal para fins penais deverá ser arquivada, depois de incluir nos autos cópia da respectiva decisão administrativa.

${ }^{106}$ SILVA, Gustavo Henrique de Souza e. Op. cit. p. 125 
II - recolher contribuições devidas à previdência social que tenham integrado despesas contábeis ou custos relativos à venda de produtos ou à prestação de serviços;

III - pagar benefício devido a segurado, quando as respectivas cotas ou valores já tiverem sido reembolsados à empresa pela previdência social."

Nesse caso, diferentemente do crime de descaminho, não precisaremos demonstrar se o crime em exame seria contra a ordem tributária, vez que a arrecadação previdenciária está inclusa dentro da arrecadação tributária lato sensu. ${ }^{107}$

Em relação à natureza do crime de apropriação indébita previdenciária, também dependeríamos de reconhecer que a mesma fosse de cunho material, para a possibilidade de aplicarem-se as observações trazidas pelo julgamento do HC 81.611.

Nesse sentido, não foi outro o entendimento aplicado pelo STJ, no julgamento do AgHc 10.488/CE, de Relatoria da Min. Jane Silva, que concluiu ser o delito de apropriação indébita previdenciária crime omissivo material, pois para sua necessária configuração é preciso exigir o efetivo desconto do dinheiro e a sua indevida apropriação, gerando a lesão do patrimônio da previdência social, como ementado abaixo:

"PENAL - AGRAVO REGIMENTAL EM HABEAS CORPUS - APROPRIAÇÃO INDÉBITA PREVIDENCIÁRIA - TRANCAMENTO DE INQUÉRITO POLICIAL - INSTAURAÇÃO EM CONCOMITÂNCIA COM O PROCESSO TRIBUTÁRIO ADMINISTRATIVO - INEXISTÊNCIA DE LANÇAMENTO DEFINITIVO DO QUANTUM DEVIDO - DISCUSSÃO SOBRE A EXIGIBILIDADE DO TRIBUTO - RECENTE ORIENTAÇÃO JURISPRUDENCIAL DO SUPREMO TRIBUNAL FEDERAL - TRANCAMENTO -SUSPENSÃO DO CURSO DO PRAZO PRESCRICIONAL - CONSTRANGIMENTO ILEGAL EVIDENCIADO NEGADO PROVIMENTO AO AGRAVO.

1. O trancamento de inquérito policial somente é viável ante a cabal e inequívoca demonstração da atipicidade do fato ou da completa inexistência de qualquer indício de autoria em relação aos pacientes.

2. Consoante recente orientação jurisprudencial do egrégio Supremo Tribunal Federal, seguida por esta Corte, eventual crime contra a ordem tributária depende,

${ }^{107}$ Ibid. p. 126. 
para sua caracterização, do lançamento definitivo do tributo devido pela autoridade administrativa.

3. Na mesma linha, o Pleno da Suprema Corte entendeu ser necessário o término do processo administrativo que discuta a exigibilidade do tributo no que pertine ao delito de apropriação indébita previdenciária.

4. Negado provimento ao agravo regimental." (STJ, AgHC 109.488, Rel. Ministra Jane Silva, Brasília, 13 out. de 2008.)

Importante esclarecer que no julgado, também foram abordadas as questões levantadas no julgamento do HC 81.611, no que tange aguardar a decisão final do processo administrativo, para iniciar-se a persecução penal, pois também confirmada a natureza de crime material.

Nessa linha Marta Saad e Diogo Malan, apontam as semelhanças entre os crimes de apropriação indébita e sonegação previdenciária, e os delitos tipificados no artigo $1^{\circ}$ da Lei $8137 / 90$, sendo todos de aspecto material. ${ }^{108}$

Curioso abordar, que no deslinde do julgamento, foi levantado pelo Ministério Público o argumento de não haver uma Súmula Vinculante para ser feita essa equiparação aos crimes contra a ordem tributária. Tese essa rechaçada pelo colegiado, ao entender que existiriam as mesmas condições dos crimes fiscais, inclusive sua natureza material, que no caso, era omissiva.

Essa equiparação, também estava sendo feita pelo próprio Supremo, tanto que no julgamento do Inq-Ag 2.537/ Goiás ${ }^{109}$, de relatoria do Ministro Marco Aurélio, ficou consignado que o crime em análise era omissivo material, e não simplesmente formal. Por fim, também ficou afastada a possibilidade de

\footnotetext{
${ }^{108}$ SAAD, Marta \& MALAN, Diogo. Crimes contra a ordem tributária e a portaria SRF: Novo esforço para restaurar a lógica do sistema. Boletim do Instituto Brasileiro de Ciências Criminais, São Paulo, $\mathrm{n}^{\circ}$ 150, p. 11-12, maio de 2005. p. 11

${ }^{109}$ APROPRIAÇÃO INDÉBITA PREVIDENCIÁRIA - CRIME - ESPÉCIE. A apropriação indébita disciplinada no artigo 168-A do Código Penal consubstancia crime omissivo material e não simplesmente formal. INQUÉRITO - SONEGAÇÃO FISCAL - PROCESSO ADMINISTRATIVO. Estando em curso processo administrativo mediante o qual questionada a exigibilidade do tributo, ficam afastadas a persecução criminal e - ante o princípio da não-contradição, o princípio da razão suficiente - a manutenção de inquérito, ainda que sobrestado. (STF, INQ 2537/Agr, Rel. Ministro Marco Aurélio, Brasília, 10 mar. de 2008.)
} 
persecução penal, mesmo em sede de inquérito policial, havendo processo administrativo em curso para apurar a exigibilidade do crédito.

Assim, a aplicação dos motivos que levaram ao julgamento do leading case HC 81.611 e à edição da Súmula Vinculante ${ }^{\circ}$ 24, devem servir de base para a solução nos casos de apropriação indébita previdenciária e de descaminho.

Vale dizer que a representação fiscal para fins penais, no que tange aos crimes previdenciários, era regulamentada pela Instrução Normativa INSS/DC $\mathrm{n}^{\mathrm{o}} 100$ de 18 de dezembro de 2003. Ocorre que, a leitura dos artigos $140 \S 5^{\circ}$, 168, e 634 deste diploma legal, aparentemente previam o encaminhamento da representação fiscal para fins penais, nos crimes previdenciários, antes mesmo da efetiva apuração e constituição do crédito devido. ${ }^{110}$

Posteriormente, com a criação do Sistema da Super Receita, esta Instrução Normativa, foi revogada por outra mais recente, Instrução Normativa RFB 971/2009, alterada pela atual Instrução Normativa RFB 1.071/2010. Contudo, no que se referia a representação fiscal, a letra dos dispositivos ficou, praticamente inalterada, só mudando a numeração - agora, artigos $102 \S 5^{\circ}{ }^{111}$, e Art. $132 .^{112}$

De qualquer jeito, a Portaria RFB, $n^{\circ} 665$, já analisada no começo deste trabalho, veio esclarecer a controvérsia, ao equiparar e regulamentar a representação fiscal dos crimes previdenciários, da mesma maneira que nos crimes tributários, só permitindo o encaminhamento da representação fiscal, após o lançamento definitivo.

\footnotetext{
${ }^{110}$ SAAD, Marta \& MALAN, Diogo. Op. cit. 11

${ }^{111} \S 5^{\circ}$ Cabe ao reclamado comprovar o recolhimento da contribuição anteriormente descontada do segurado reclamante, sob pena de comunicação à Delegacia ou Inspetoria da Receita Federal do Brasil, para apuração e constituição do crédito, nas formas previstas no Capítulo I do Título VII, e Representação Fiscal para Fins Penais.

${ }^{112}$ Art. 132. A falta de recolhimento, no prazo legal, das importâncias retidas configura, em tese, crime contra a Previdência Social previsto no art. 168-A do Código Penal, introduzido pela Lei ${ }^{\circ}$ 9.983, de 14 de julho de 2000, ensejando a emissão de Representação Fiscal para Fins Penais (RFFP).
} 
De igual forma, a recentíssima Medida Provisória 497/2010 alterou a escrita do artigo 83 da Lei 9430/96, para incluir os crimes previdenciários no dispositivo da representação fiscal, só permitindo que a remessa ao MP, seja feita após a decisão final na esfera administrativa. ${ }^{113}$

Logo, como os crimes previdenciários - apropriação indébita previdenciária - além de possuírem os mesmos motivos da aplicação do HC 81.611, e da Súmula Vinculante ${ }^{\circ}$ 24, agora, também estão regulamentados pelos mesmos atos normativos. E assim, para solucionar a omissão da Súmula, como já sugerido, seria interessante ou a edição de novo verbete sumular complementar ou no mínimo revisão da Súmula Vinculante nº 24.

\section{3 - A Máxima da Proporcionalidade}

Por tudo até aqui exposto, percebemos que toda a discussão da matéria está vinculada a um conflito entre Direitos Fundamentais. Como abordado no início deste trabalho, de um lado temos os direitos à ampla defesa e ao contraditório - o direito do contribuinte de se defender no processo administrativo, na esfera fiscal, para só depois poder se cogitar da persecução penal - e do lado oposto, o direito ao acesso à justiça e o poder-dever de punir do Estado - o MP não pode ficar impedido de iniciar a ação penal, muito menos perder sua atribuição de exercer o poder-dever de punir.

Assim, será necessário analisarmos estudos como os tipos de colisão entre direitos fundamentais, seus motivos e suas possíveis soluções para chegarmos

\footnotetext{
${ }^{113}$ Art. 11 . O art. 83 da Lei no 9.430, de 27 de dezembro de 1996, passa a vigorar com a seguinte redação:

“Art. 83. A representação fiscal para fins penais relativa aos crimes contra a ordem tributária previstos nos arts. $1^{\circ}$ e $2^{\circ}$ da Lei $\mathrm{n}^{\mathrm{o}}$ 8.137, de 27 de dezembro de 1990, e aos crimes contra a Previdência Social, previstos nos arts. 168-A e 337-A do Decreto-Lei no 2.848, de 7 de dezembro de 1940 - Código Penal, será encaminhada ao Ministério Público depois de proferida a decisão final, na esfera administrativa, sobre a exigência fiscal do crédito tributário correspondente."
} 
a uma resposta quanto a um ponto ápice da matéria, qual seja a espera da representação fiscal para fins penais.

\subsection{1 - A colisão entre Direitos Fundamentais}

Quando falamos em colisão de direitos fundamentais, podemos considerála em sentido estrito, e em sentido amplo.

Segundo Robert Alexy ${ }^{114}$, quando há uma colisão entre direitos fundamentais, exclusivamente com outros direitos fundamentais, falamos de colisão em sentido estrito - o exercício ou a realização de direitos fundamentais de um titular tem consequiências negativas sobre os diretos fundamentais de outro titular de direitos fundamentais. Por outro lado, quando os direitos fundamentais entram em conflito com quaisquer normas ou outros princípios, que tenham como objeto bens coletivos, ou com outros direitos fundamentais, temos o sentido amplo.

Nos direitos fundamentais colidentes, em sentido estrito, pode se tratar de direitos idênticos, ou de diversos. Quando idênticos, podem distinguir-se em quatro tipos: No primeiro, está afetado o mesmo direito fundamental, em ambos os lados, como o direito de defesa liberal; No segundo, trata-se do mesmo direito fundamental, só que dessa vez, um lado está como direito de defesa liberal, e o outro está como direito de proteção do outro - o objeto imediato desse dever de proteção é um bem coletivo: a segurança pública; No terceiro, a colisão resulta de que muitos direitos fundamentais possuem um lado positivo e outro negativo; O quarto resulta quando se acrescenta ao lado jurídico de um direito fundamental um lado fático. ${ }^{115}$

\footnotetext{
114 ALEXY, Robert. Colisão de direitos fundamentais e a realização de direitos fundamentais no Estado de Direito Democrático. Revista de Direito Administrativo, Rio de Janeiro, n217, p. 67-79, jul./set. 1999. p. 68

${ }^{115}$ Alexy exemplifica cada um dos quarto tipos. Ibid. p. 69/70
} 
Por outro turno, quando abordado o sentido amplo, é necessário ter em mente que os bens coletivos não são apenas, naturalmente, adversários de diretos individuais, pois também podem servir como pressupostos ou meios de seu cumprimento ou fomento. ${ }^{116}$ Isto ocorre quando, ao visar ao bem coletivo também se atinge o particular, afinal este está inserido naquele.

De qualquer sorte, mesmo vendo a questão da colisão em sentido amplo ou em sentido estrito, o fato em comum é que todas as colisões podem somente ser solucionadas se, de alguma maneira, houver limitações ou sacrifícios de um lado ou do outro.

Ocorre que, antes de adentramos as limitações, é preciso expor acerca da estrutura fundamental da dogmática dos direitos fundamentais, na forma de duas decisões fundamentais.

Os direitos fundamentais possuem força vinculativa, pois se assim não fossem, todas as colisões, como problema jurídico, desapareceriam, pois não teriam força para se auto-sustentarem. Tanto na Alemanha, quanto no Brasil, prevalece a tese da força vinculante, quando, ao mencionar que as prescrições de direitos fundamentais, em suas Constituições, seriam diretamente aplicáveis. Assim, esta seria a primeira decisão fundamental para os direitos fundamentais. ${ }^{117}$

A segunda decisão fundamental seria estabelecer se os direitos fundamentais teriam o caráter de regras ou princípios. Adianta-se, desde logo, que possuem caráter de princípios, pois são tratados como mandamentos de otimização, e não como mandamentos definitivos, o que seriam caso se assemelhassem às regras.

\footnotetext{
${ }^{116}$ Um excelente exemplo é quando a indústria de Tabaco tem o dever legal de colocar advertências sobre prejuízo a saúde em seus produtos, sendo uma intervenção na liberdade de exercício profissional dos produtores de tabaco, portanto, em um direito fundamental. Nesse caso, vemos como justificação a proteção da população diante do risco à saúde, prevalecendo um bem coletivo. Ibid. p.71

${ }^{117}$ Ibid. p. 73-74
} 
Isto porque "princípios são normas que ordenam que algo seja realizado em uma medida tão ampla quanto possível relativamente à possibilidade fática ou jurídica" ${ }^{118}$, e a maneira de solucionar a colisão de direitos fundamentais, seria através de uma ponderação. $\mathrm{O}$ mesmo já não ocorre no caso das regras, que possuem como solução a subsunção, pois são normas que podem ser cumpridas ou não cumpridas, possuindo determinações limitadas, uma vez que só ordenam fazer aquilo que pedem, nem mais, nem menos.

Além disso, a solução entre um conflito de regras só ocorre quando é introduzida uma cláusula de exceção que elimine o conflito em si, ou se uma das regras for declarada inválida, enquanto que a colisão de princípios deve ser solucionada de maneira diferente. ${ }^{119}$

Isto porque, caso dois princípios colidam, um deles terá que ceder, não significando que um deles será declarado inválido, nem que será introduzida uma clausula de exceção. Como assevera Alexy: "Na verdade, o que ocorre é que um dos princípios tem precedência em face do outro sob determinadas condições." ${ }^{120}$ Ou seja, no caso dos princípios, os mesmos possuem pesos diferentes e os princípios com maior peso têm prevalência sobre os demais.

Dessa maneira, o caminho certo para solucionar-se a questão das colisões, é utilizar a Teoria dos Princípios.

No presente trabalho, a grande questão é qual princípio aplicar acerca da (in)dependência das esferas administrativo-fiscal e da penal. Para quem defende a tese da dependência das esferas - atual posição do Supremo Tribunal Federal - os princípios que deveriam ser aplicados seriam o da ampla defesa e do contraditório do contribuinte ao processo administrativo fiscal, enquanto

\footnotetext{
${ }^{118}$ Ibid. p. 74

${ }^{119}$ ALEXY, Robert. Teoria dos direitos fundamentais. Trad. da $5^{\text {a }}$ ed. alemã. São Paulo: Malheiros, 2008. p. 92.

${ }^{120}$ Ibid. p. 93.
} 
que quem defende a independência das esferas, entende que deveria ser aplicado o acesso a justiça, e o poder-dever de punir do Estado - garantir, na maior medida possível, a operacionalidade do direito penal.

Essa colisão acontece, pois ambos os direitos fundamentais encontram-se respaldados no artigo $5^{\circ}$ na Constituição Federal. Enquanto o inciso XXXV aduz que "a lei não excluirá da apreciação do Poder Judiciário lesão ou ameaça a direito", o inciso LV dispõe que "aos litigantes, em processo judicial ou administrativo, e aos acusados em geral são assegurados o contraditório e a ampla defesa, com meios e recursos a ela inerentes."

Para Hugo de Brito Machado ${ }^{121}$, esta questão mais do que Direito Penal, ou Processo Penal, é uma questão Constitucional, pois obrigar ao contribuinte a passar por um processo penal, sem antes ver exaurida a esfera administrativa seria negar a Supremacia Constitucional. Isto porque, como cobrar ou condenar alguém por um crime que ainda não se sabe o quanto é devido, ou sonegado?

No mesmo sentido, assevera Suzana Farias Machado de Moraes ${ }^{122}$ ao entender que aceitando uma instrução criminal, antes de exaurida a esfera administrativa, seria negar totalmente o direito de ampla defesa do contribuinte. Da mesma maneira, poderia entender que ao aceitar uma denúncia antes de concluída a esfera fiscal, poderia aumentar a arrecadação do Estado, mas estaria cerceando o pleno direito do contribuinte a ampla defesa, impedindo que esse se defenda no procedimento administrativo. A autora ainda faz uma ressalva de que não seria justo iniciar uma persecução penal, e no seu transcorrer ficar comprovado que o acusado realmente não suprimiu, nem reduziu tributos, anulando assim todo o processo - como ficaria o constrangimento passado por este?

\footnotetext{
${ }^{121}$ MACHADO. Hugo de Brito. Op. cit. p. 237

${ }^{122}$ MORAES, Suzane de Farias Machado. Op. cit. p.89
} 
Do outro lado, quem defende o princípio do acesso a justiça, inafastabilidade do Poder Judiciário, entende que o Judiciário recebeu um poder constitucional da jurisdição, e lhe retirada essa garantia e entregue a outro poder - como no caso ao Executivo - para julgar a instância administrativa, seria violar este princípio da inafastabilidade, bem como a divisão entre os três poderes. ${ }^{123}$

Dessa maneira, resta clara a colisão frontal entre esses dois princípios. Ao prestigiar um deles, estaríamos desfavorecendo o outro. Como fazer para solucionar essa questão? Como analisar a maneira correta de aplicá-los sem causar prejuízo a outra parte?

Novamente, à luz das sábias palavras de Alexy ${ }^{124}$ : "Esses deveres devem ser aplicados na medida das possibilidades fáticas e jurídicas de sua realização". Isto porque, se houvesse apenas o direito de acesso à justiça inafastabilidade do Poder Judiciário - e o poder-dever de punir operacionalidade do direito penal -, a deflagração da ação penal, antes de encerrada a esfera administrativa, seria obrigatória. Por outro lado, se houvesse apenas o princípio da ampla defesa e do contraditório do contribuinte no procedimento administrativo, o poder-dever de punir do Estado - mais precisamente - a capacidade de propor a ação penal do Ministério Público por qualquer meio, estaria prejudicada.

Portanto, se isoladamente considerados, ambos os princípios conduzem a uma contradição, significando dizer que um princípio restringe as possibilidades jurídicas de realização do outro. Assim, a solução para essa

\footnotetext{
${ }^{123}$ WIGGERS, Gustavo \& BISSOLI FILHO, Francisco. Op. cit. 14

${ }^{124}$ ALEXY, Robert. Teoria dos direitos fundamentais. p. 95
} 
colisão consiste na fixação de uma relação de precedência condicionada entre os princípios, no caso concreto. ${ }^{125}$

Desta maneira, é valiosa a vantagem da teoria dos princípios, pois acaba por "evitar um tal correr no vazio dos direitos fundamentais sem conduzir ao entorpecimento". De acordo com ela, uma intervenção em direitos fundamentais só poderá ser justificada se estiver com base numa ponderação. ${ }^{126}$

Nesse sentido, Daniel Sarmento ${ }^{127}$ esclarece muito bem essa questão da ponderação, quando afirma que:

\begin{abstract}
"Tem-se entendido que o caráter principiológico das normas constitucionais protetivas dos direitos fundamentais permite ao legislador que, através de uma ponderação constitucional dos interesses em jogo, estabeleça restrições àqueles direitos, sujeitas, no entanto, a uma série de limitações (são os chamados "limite dos limites")."
\end{abstract}

\title{
4.3.2 - A estrutura da ponderação - conjunto da proporcionalidade
}

Devemos ter em mente que, quando a doutrina fala em ponderação está a se referir a um mandamento que corresponde a um terceiro princípio parcial do princípio da proporcionalidade do Direito Constitucional Alemão. ${ }^{128}$

Dessa forma, o princípio da proporcionalidade, subdivide-se em três princípios parciais: adequação; necessidade; e proporcionalidade em sentido estrito. Na adequação, exige-se que as medidas adotadas pelo Poder Público se

\footnotetext{
${ }^{125}$ Ibid. p. 96

${ }^{126}$ ALEXY, Robert. Colisão de direitos fundamentais e a realização de direitos fundamentais no Estado de Direito Democrático. p. 77

${ }^{127}$ SARMENTO, Daniel. Colisões entre direitos fundamentais e interesses públicos, In: SARMENTO, Daniel, GALDINO, Flávio (Orgs.). Direitos Fundamentais: Estudos em homenagem ao professor Ricardo Lobo Torres, p. 267-324. Rio de Janeiro: Renovar, 2006. p. 293

${ }^{128}$ ALEXY, Robert.. . Colisão de direitos fundamentais e a realização de direitos fundamentais no Estado de Direito Democrático. p. 77
} 
mostrem aptas a atingir os objetivos pretendidos; Na necessidade, impõe-se a verificação da inexistência de meio menos gravoso para se atingir os fins visados; e o da proporcionalidade em sentido estrito seria a ponderação entre o ônus imposto e o benefício trazido, para verificar se a interferência é justificável. ${ }^{129}$

Vale ressaltar que os três princípios, com base na teoria dos princípios, estão munidos com idéia de otimização - ordenam que algo seja realizado, relativamente às possibilidades fáticas e jurídicas, em medida tão alta quanto possível. Enquanto a adequação e necessidade estariam vinculadas às possibilidades fáticas, a proporcionalidade em sentido estrito estaria às possibilidades jurídicas.

A adequação e a necessidade estão ligadas à idéia de eficiência de Pareto: "uma posição pode ser melhorada sem que uma outra seja piorada". ${ }^{130} \mathrm{Ou}$ seja, quando houver a possibilidade de escolher entre duas medidas distintas para solução de um conflito deverá ser escolhida a que menos prejudica a outra posição.

No que tange a adequação/idoneidade a idéia que deve prevalecer é a de que devem ser utilizados princípios para a otimização dos direitos fundamentais. A adequação só funciona para possibilidades fáticas. Como aplicar isto ao caso concreto? Bem, exemplificando: tomemos como premissa dois princípios, e para aplicá-los apenas uma medida que não prejudica nem um nem outro. Sem dúvidas aplica-se a medida. Paralelo à isso, como segunda premissa, temos dois princípios e uma medida que prejudica um deles. Deve-se desconsiderar esta medida e aplicar-se os dois princípios. Ou seja, deve-se optar por uma posição que pode ser melhorada sem que nasçam desvantagens para as outras. Assim, os dois princípios, considerados em conjunto, são

\footnotetext{
${ }^{129}$ SARMENTO, Daniel. Op. cit. 309

${ }^{130}$ ALEXY, Robert. Teoria dos direitos fundamentais. p. 589/591
} 
realizados em maior grau, relativamente às possibilidades fáticas, caso se abdique da medida adotada.

Em nosso caso, testando a máxima da adequação, temos que se aplicarmos a medida de iniciar a persecução penal de imediato, sem aguardar o esgotamento da esfera administrativa, o princípio do acesso a justiça estaria sendo consagrado, em desfavor ao da ampla defesa. Dessa maneira, a aplicação do princípio não estaria sendo adequada, pois ao aplicar essa medida, um princípio estaria sendo prejudicado - no caso a ampla defesa. Ao contrário, se não fosse utilizado esta medida sugerida, ambos os princípios de ampla defesa e acesso a justiça, caso considerados conjuntamente, seriam aplicados em maior grau. Ou seja, uma posição poderá ser melhorada sem que outra seja piorada.

Diante disto, Alexy ${ }^{131}$ explica o insucesso da aplicação da máxima da adequação:

“...se não se pretende abandonar a máxima da adequação, não é possível passar ao largo de algum tipo de otimização. Ele demonstra, além disso, que o aspecto da otimização presente na máxima da adequação não aponta para outra máxima. Essa máxima tem, na verdade, a natureza de um critério negativo. Ela elimina meios adequados. Um tal critério negativo não determina tudo, exclui algumas coisas. Nesse sentido, ele ajusta-se a idéia de uma ordem-moldura. Como elemento de uma ordem como essa, ele exclui algumas coisas - a saber: aquilo que não é adequado sem, com isso determinar tudo."

Adiante, a parcial/requisito da necessidade, possui dois meios, que em geral, fomentam igualmente um dos princípios. Diante disto, se existe um meio intensivamente interveniente e igualmente idôneo, entre dois meios aproximadamente adequados, deve ser escolhido aquele que intervenha de modo menos intensivo.

${ }^{131}$ Ibid. p. 590 
Em nosso caso, temos uma medida como a de não aguardar o fim da esfera administrativa para se iniciar uma persecução penal, e como outra medida temos a possibilidade do Ministério Público deflagrar a ação penal por outros meios que não sejam quanto à representação fiscal, como no caso de uma noticia criminis por parte de outras pessoas, ou se por algum meio souber da prática de algum crime fiscal, sem ser por agentes fazendários.

Diante desses dois meios, de acordo com a parcial da necessidade, deveria ser escolhido aquele meio que interviesse de maneira menos gravosa no outro princípio, a ampla defesa do contribuinte.

Nesse caso, a escolha da segunda medida, mesmo não sendo ideal para o principio da ampla defesa, afeta menos intensamente o princípio da ampla defesa.

Ocorre que se ambas as medidas embaraçam a realização do princípio da ampla defesa e uma medida o faz em menor escala que a outra medida, então as duas medidas não esgotam o campo das possibilidades fáticas para realização de um dos princípios - ampla defesa - nem mesmo se as duas medidas fossem as únicas medidas adequadas para realização do objetivo de independência das instâncias, exigido pelo princípio de acesso a justiça.

O exame da necessidade permite apenas privilegiar uma medida em face da outra. $\mathrm{O}$ fato de que uma das alternativas tenha que ser escolhida não seria uma questão de possibilidade fática, e sim uma questão de possibilidade jurídica, ou seja, uma questão de ponderação entre os dois princípios (proporcionalidade em sentido estrito). Por isso, até quando um meio menos gravoso afete a realização de um dos princípios - ampla defesa, o exame da necessidade 
deverá ser seguido sempre pelo exame da proporcionalidade em sentido estrito. $^{132}$

Nessa linha, é que nem sempre os casos concretos estarão vinculados apenas às medidas, e nem, a dois princípios. Quando houver um terceiro princípio, que pelo emprego dos meios menos intensivamente intervenientes em um dos outros dois princípios, um deles será afetado negativamente. Dessa maneira, não caberá a preferência Pareto, e havendo custos ou sacrifícios, será necessária uma ponderação. ${ }^{133}$

Destarte, Alexy aduz que "a ponderação é objeto do terceiro princípio parcial do princípio da proporcionalidade", qual seja, o principio da proporcionalidade em sentido estrito. E equipara com a regra da "lei da ponderação", que dispõe: "Quanto mais alto é o grau do não-cumprimento ou prejuízo de um princípio, tanto maior deve ser a importância do cumprimento". ${ }^{134}$

Sob a luz dessa lei, o Autor demonstrou que a ponderação se decompunha em três passos: ${ }^{135}$

"Em um primeiro passo deve ser comprovado o grau do não-cumprimento ou prejuízo de um princípio. A isso deve seguir, em um segundo passo, a comprovação da importância do cumprimento do princípio em sentido contrário. Em um terceiro passo deve, finalmente, ser comprovado, se a importância do cumprimento do princípio em sentido contrário justifica o prejuízo ou não-cumprimento do outro."

Dessa maneira, através da proporcionalidade em sentido estrito ponderação - é que devemos solucionar a colisão entre princípios.

\footnotetext{
${ }^{132}$ Ibid. p. 119.

${ }^{133}$ ALEXY, Robert. Direitos fundamentais, ponderação e racionalidade. Revista de Direito Privado, São Paulo, n. 24, p. 334-344, out./dez. 2005. Tradução de Luis Afonso Heck. p. 339

${ }^{134}$ Ibid. 339

${ }^{135}$ Ibid. 339/340
} 
Isso posto, devemos agora retornar ao nosso caso concreto, objeto do presente estudo, para aplicarmos a lei.

O primeiro passo seria analisarmos o grau de prejuízo da não aplicação dos princípios de acesso ao judiciário por parte do Ministério Público, e aplicação do poder-dever de punir. Caso estes princípios fossem extirpados totalmente, teríamos um prejuízo de nível grave, pois abriria uma grande margem à impunidade, e praticamente estar-se-ia convidando os contribuintes a cometerem crimes fiscais. Por outro lado, com a possibilidade de só se iniciar a persecução penal após exaurida a esfera administrativa, o acesso à justiça do MP, bem como o poder-dever de punir sofreriam um prejuízo leve, quiçá médio. Pois os princípios restariam resguardados para depois, na esfera penal, caso o contribuinte não lograsse êxito em sua defesa na esfera administrativa.

O segundo passo demonstra a importância dos princípios da ampla defesa e do contraditório do contribuinte no procedimento fiscal ("princípio em sentido contrário"). Se o contribuinte tem a possibilidade de se defender por todos os meios possíveis, contra qualquer acusação na esfera administrativa, e se vier a obter uma decisão favorável, não precisa passar, de maneira alguma, por qualquer constrangimento referente à persecução penal pré-matura.

O que não ocorreria se os papéis se invertessem, ou seja, se mitigássemos a ampla defesa do contribuinte, em prol do direito de punir do Estado/acesso a justiça. O suposto réu passaria por diversas fases de um processo criminal, tendo que suportar muitos sentimentos desgostosos, muita aflição - afinal todos nós sabemos o quão doloroso e penoso poderá ser uma instrução de um processo criminal - sem qualquer necessariedade, pois ainda poderia ver sua defesa na esfera administrativa lograr êxito, gerando nulidade de todo um processo penal, ou trancamento de algum suposto inquérito policial. 
Dessa maneira, chegamos ao terceiro passo comprovando que a intervenção aos princípios do MP, foi feita de uma maneia proporcional, resguardando os direitos de ambos os lados. Afinal, caso haja decisão final irrecorrível da esfera administrativa contra o contribuinte - lançamento definitivo do tributo, o Estado ainda poderá perseguir aquele sujeito criminalmente.

Logo, a atual posição do STF encontra-se respaldada na Máxima da Proporcionalidade vez que, de uma maneira ponderada, garantiu o direito de ambos os lados, não agindo de maneira desproporcional.

\section{4 - Perspectivas de reforma legislativa}

Conforme sugerido, deveriam ser propostos projetos de lei para solucionar as questões aqui levantadas. Ocorre que, atualmente tramitam no Congresso Nacional, mais especificamente por propositura da Câmara dos Deputados, projetos em sentido contrário.

Os Projetos de Lei $\mathrm{n}^{\mathrm{o}}$ 3.670/2004 - Autor: Deputado Paulo Rubem Santiago; 1.606/2007 - Autor: Deputado João Campos; e 7321/2010 - Autora: Luciana Genro - tratam da mesma matéria, abordando, praticamente, as mesmas questões, e também propondo soluções muito parecidas. Tanto é assim, que os três tramitam juntos, apensados uns aos outros. Dessa forma, será feita uma análise das idéias desses projetos, numa visão geral, e não específica de cada.

O primeiro ponto levantado nos Projetos é a alteração da estrutura dos crimes contra a ordem tributária. De início, o primeiro Projeto - 3670/2004 sugeriu que todos os crimes previstos na Lei 8137/90, bem como os crimes contra a Previdência Social, fossem transformados em crimes formais, através da modificação do texto da lei. Já os outros dois Projetos de Lei almejavam a 
mudança da estrutura típica, elencando exatamente cada conduta típica como crime formal.

Esta mudança teria a intenção de não mais incriminar o agente pelo resultado - supressão ou redução de tributos - mas sim pela intenção do agente em não pagar os tributos a partir de uma conduta criminosa ou fraudulenta objetivando-se punir a fraude. Isto porque o atual entendimento jurisprudencial de nossos Tribunais Superiores, bem como a doutrina majoritária, é no sentido de que os casos que versem sobre essa matéria só poderiam chegar ao Judiciário caso houvesse o resultado alcançado.

O mesmo entendimento também é aplicado aos inquéritos policiais, o que dificulta a função do Fisco, pois as unidades policiais poderiam auxiliar na tarefa dos Agentes Fazendários.

Assim, com a transformação dos crimes em natureza formal, não haveria a necessidade de se aguardar a comprovação de redução, ou supressão de tributos, visto que a mera conduta já seria suficiente para iniciar a persecução penal. Pensando por um viés mais extremista, essa solução levaria a uma aceleração dos processos fiscais, pois não precisando comprovar a obtenção de resultado, o MP poderia iniciar desde logo a persecução penal, e havendo uma eventual condenação, operaria como desestímulo à prática de crimes fiscais, por outros agentes.

A nosso ver, essa primeira alteração não deverá prosperar, pois seria uma maneira de alterar inúmeros dispositivos, apenas com o intuito de tentar desviar a aplicação do entendimento já pacificado pelos Tribunais Superiores. Isto porque se todos os crimes fossem formais, os longos anos gastos para encontrar uma boa solução, e proteger o bem jurídico tutelado - ou o erário, ou a relação contribuinte-fisco - estariam sendo postos de lado, para satisfazer uma obsessão em punir. 
Dessa forma estaria sendo violado o princípio da ofensividade. O ilustre Professor Luiz Flávio Gomes ${ }^{136}$ explica de forma clara as funções deste princípio:

\begin{abstract}
"dupla é a função do princípio da ofensividade no Direito Penal: (a) função políticocriminal (momento em que se decide pela criminalização da conduta) e (b) função interpretativa ou dogmática (instante em que se interpreta e se aplica concretamente o Direito Penal). A primeira função do principio da ofensividade constitui um limite ao direito de punir do Estado (ao ius puniendi). Está dirigida ao legislador. A segunda configura um limite ao Direito penal (ao ius poenale). Está dirigida ao intérprete e ao juiz (ao aplicador da lei penal). De qualquer modo, impõe-se enfatizar que não são duas funções estanques (e incomunicáveis). Ao contrário, são complementares. Tanto assim que, quando o legislador não cumpre seu papel de criminalizar a conduta em termos ofensivos a um bem jurídico, essa tarefa se transfere (improrrogavelmente) ao intérprete e ao juiz."
\end{abstract}

Então, observamos que quando o legislador ordinário editou a lei 8.137/90, tipificando os crimes contra a ordem tributária, - e o mesmo no caso de crimes previdenciários - este delimitou o ius puniendi do Estado, pois deixou claro que a conduta - artigo $1^{\circ}$ da lei $8137 / 90$, crimes de resultado material - que iria reprimir era a de reduzir, ou suprimir tributos. Por anos foi discutido qual seria, ao certo, o bem juridicamente tutelado nesses crimes, se era o erário público, ou outro, como a relação fisco-contribuinte. A ofensividade, em sua segunda função, veio a definir essa controvérsia, através da interpretação da lei pelo aplicador, e, portanto, a melhor corrente entendeu tratar-se do erário público.

Assim, novamente leciona Luis Flavio Gomes “o bem jurídico, sendo o objeto de proteção da norma, passa a ser relevante para a lei penal positiva, que é o veiculo mediante o qual se expressam as normas jurídicas." 137

Desse raciocínio, entende-se que mudar a estrutura desses crimes fiscais, depois de passado todo esse processo de definir/limitar o ius puniendi, seria

\footnotetext{
${ }^{136}$ GOMES, Luiz Flávio. Princípio da ofensividade no direito penal: não há crime sem lesão ou perigo concreto de lesão ao bem jurídico (nullun crimen sine iniuria), funções politico-criminal e dogmáticainterpretativa, o princípio da ofensividade como limite do ius puniedi, o princípio da ofensividade como limite do ius poenale. São Paulo: Editora Revista dos Tribunais, 2002. p. 28

${ }^{137}$ Ibid. 109
} 
violar gravemente o principio da ofensividade, pois, o bem tutelado já foi definido, e em torno dele construíram-se todos os meios de aplicar a repressão penal, e outros meios de se lidar com esse delito, até no caso de utilizarem-se benefícios.

Além disso, esta alteração sugerida pelos projetos de lei estaria a contrariar interpretação já conferida à matéria pelo STF. E, dessa maneira, vale lembrar que como ficou decidido no julgamento da ADIn 2.797-2 ${ }^{138}$ - embora julgado caso/crime totalmente diferente - o Excelso Pretório entendeu não ser facultado ao legislador ordinário fazer, via reforma legislativa, interpretação autêntica da Constituição da República que seja diametralmente contrária àquela já feita pelo STF.

Logo, transformar todos os crimes contra a ordem tributária e previdenciária em crimes de cunho formal estaria indo contra o entendimento

138 III. Foro especial por prerrogativa de função: extensão, no tempo, ao momento posterior à cessação da investidura na função dele determinante. Súmula 394/STF (cancelamento pelo Supremo Tribunal Federal). Lei 10.628/2002, que acrescentou os $\$ \S 1^{\circ}$ e $2^{\circ}$ ao artigo 84 do C. Processo Penal: pretensão inadmissível de interpretação autêntica da Constituição por lei ordinária e usurpação da competência do Supremo Tribunal para interpretar a Constituição: inconstitucionalidade declarada.

1. O novo $\S 1^{\circ}$ do art. 84 CPrPen constitui evidente reação legislativa ao cancelamento da Súmula 394 por decisão tomada pelo Supremo Tribunal no Inq 687-QO, 25.8.97, rel. o em. Ministro Sydney Sanches (RTJ 179/912), cujos fundamentos a lei nova contraria inequivocamente.

2. Tanto a Súmula 394, como a decisão do Supremo Tribunal, que a cancelou, derivaram de interpretação direta e exclusiva da Constituição Federal.

3. Não pode a lei ordinária pretender impor, como seu objeto imediato, uma interpretação da Constituição: a questão é de inconstitucionalidade formal, ínsita a toda norma de gradação inferior que se proponha a ditar interpretação da norma de hierarquia superior.

4. Quando, ao vício de inconstitucionalidade formal, a lei interpretativa da Constituição acresça o de opor-se ao entendimento da jurisprudência constitucional do Supremo Tribunal - guarda da Constituição -, às razões dogmáticas acentuadas se impõem ao Tribunal razões de alta política institucional para repelir a usurpação pelo legislador de sua missão de intérprete final da Lei Fundamental: admitir pudesse a lei ordinária inverter a leitura pelo Supremo Tribunal da Constituição seria dizer que a interpretação constitucional da Corte estaria sujeita ao referendo do legislador, ou seja, que a Constituição - como entendida pelo órgão que ela própria erigiu em guarda da sua supremacia -, só constituiria o correto entendimento da Lei Suprema na medida da inteligência que lhe desse outro órgão constituído, o legislador ordinário, ao contrário, submetido aos seus ditames. (STF, ADIN 2.797-2, Rel. Ministro Sepúlveda Pertence, Brasília, 15 set. de 2005.) 
da Corte Maior, que entende serem essas condutas de natureza material, sendo necessário que haja uma devida supressão, ou redução de tributos.

E como consignado, não pode por via de reforma legislativa ser modificado esse entendimento.

A segunda grande proposta era a revogação de inúmeros benefícios concedidos aos contribuintes, como a extinção da punibilidade do delito pelo pagamento do tributo ou da contribuição social, e também acabar com a suspensão da pretensão punitiva do Estado.

A importância desses dois institutos deve ser entendida no âmbito de que só poderá existir a extinção da punibilidade pelo pagamento do tributo e a suspensão da pretensão punitiva do Estado pelo parcelamento caso haja um tributo devido. E o quantum debeatur só estará pronto quando exaurida a esfera administrativa. Caso não haja mais a necessidade de aguardar a esfera administrativa, por só haver crimes formais, esses benefícios não poderão ser utilizados.

Nessa linha podemos citar o artigo $7^{\circ}$ do Projeto de Lei $7321 / 2010$, que dispõe:

\footnotetext{
"Art. $7^{\circ}$. Sem embargo de incentivos que sejam dados a contribuintes na esfera administrativa ou judicial para a quitação de tributos dos quais são meros inadimplentes, quando houver a prática de crime é vedada a suspensão da pretensão punitiva do Estado e a extinção da punibilidade pelo pagamento dos tributos ou contribuições previdenciárias."
}

Ao revogar todos os dispositivos que eram utilizados como benefícios ao contribuinte, os Projetos de Lei estariam de certa maneira, tratando os crimes fiscais de modo mais severo, ao vedar que o contribuinte, e/ou possível sonegador, tivessem como devolver o imposto não pago. Esta medida traria inúmeros prejuízos, pois quando o contribuinte se vê na possibilidade de pagar o tributo, extinguindo sua punibilidade, ele o faz para livrar-se de 
conseqüências penais. Agindo dessa forma, ponderando os lados, o contribuinte/eventual sonegador acaba devolvendo o dinheiro sonegado, o que, de certa forma, faz com que o mesmo volte ao patrimônio do Estado, recompondo o erário.

A suspensão da pretensão punitiva, através das diversas formas de parcelamento, também ajuda a recompor o patrimônio do Estado, pois muitas vezes, o contribuinte não tem como devolver todo o dinheiro de uma só vez às vezes, por estar passando por dificuldades financeiras, ou por não ter capital em mãos para que naquele instante possa saldar sua suposta dívida com o Estado.

Outra inovação ligada ao pagamento do tributo seria a transformação da extinção da punibilidade pelo pagamento do tributo, em causa de diminuição da pena como demonstrado pelo artigo $4^{\circ}$ do Projeto de Lei 1606/2007:

“Art. 4". A Lei $\mathrm{n}^{\circ} .8 .137$, de 27 de dezembro de 1990, passa a vigorar acrescida do art. $12 \mathrm{~A}$, com a seguinte redação:

Art. 12 A. O pagamento integral do tributo correspondente aos crimes dos artigos $1^{\circ}$, $2^{\circ}$ e $2^{\circ} \mathrm{A}$ desta Lei será causa de diminuição de pena de um terço a metade, se realizado antes do recebimento da denúncia."

De igual forma prevê o artigo $10^{\circ}$ do Projeto de Lei 7321/2010:

"Art. $10^{\circ}$. O eventual dano causado pelas condutas criminosas que se amoldem aos tipos dos arts. $1^{\circ}$ e $2^{\circ}$ da Lei $n^{\circ} 8.137 / 90$ e aos arts. 168-A e 337-A do Código Penal, se reparado integralmente, excluídos os consectários legais, até o oferecimento da denúncia, por ato voluntário do agente, implicará a redução da pena de 1 (um) a 2/3 (dois terços), nos termos do art. 16 do Código Penal."

Dessa maneira, estar-se-ia transformando o pagamento do tributo numa causa de arrependimento posterior, previsto no artigo $16^{\circ}$ do Código Penal. ${ }^{139}$

\footnotetext{
${ }^{139}$ Arrependimento posterior
}

Art. 16 - Nos crimes cometidos sem violência ou grave ameaça à pessoa, reparado o dano ou restituída a coisa, até o recebimento da denúncia ou da queixa, por ato voluntário do agente, a pena será reduzida de um a dois terços. 
Essa alteração, apesar de inovadora, não traria grandes vantagens, tendo em vista que quem sonegou estaria sendo muito pouco beneficiando ao pagar o tributo ou contribuição social, uma vez que não escaparia de uma persecução penal, quiçá de uma possível condenação. Dessa forma, ao invés de pagar o que seria devido para livrar-se da persecução, o contribuinte/suposto sonegador optaria por não pagar - pois caso contrário, estaria confessando o crime/ sonegação - preferindo defender-se da acusação de suprimir ou reduzir tributo. Logo, nem o Estado obteria dinheiro para recompor seu patrimônio, nem o acusado iria colaborar para extinguir um processo, devolvendo o valor sonegado, atolando ainda mais a máquina do Judiciário com inúmeros processos de difíceis e longas controvérsias.

É de se observar que está inovação estaria restrita até o oferecimento da denúncia, abandonando o entendimento já consolidado de que os benefícios contra estas condutas poderiam ser aplicados a qualquer momento. ${ }^{140}$ Essa limitação ao instante do oferecimento da denúncia estaria ligada a outro ponto de suma relevância desses projetos: a necessidade de não exaurimento da esfera administrativa para iniciar a ação penal.

Pelo fato de todos os crimes tributários ou previdenciários sofrerem a possível transformação para delitos de cunho formal, como sugerido nos projetos de lei, a necessidade de se aguardar a decisão definitiva na esfera fiscal cairia por terra. Nesse sentido, todos os projetos prevêem a revogação do artigo central, estudo da presente monografia, qual seja, o artigo 83 da Lei 9430/96. O Projeto de Lei 7321/2010, em seu artigo $6^{\circ}$, explica em detalhes os motivos para a revogação, diferentemente dos demais, que apenas sugerem sua revogação:

\footnotetext{
${ }^{140}$ Vide artigo $9^{\circ} \S 1^{\circ}$ e $\S 2^{\circ}$ da Lei $10.684 / 2003$.
} 
Art. $6^{\circ}$. Os crimes previstos na Lei $\mathrm{n}^{\circ} 8.137 / 90$ e nos arts. 168-A e 337-A, ambos do Código Penal, ou correlatos, são de ação penal pública incondicionada e seu início independe de qualquer exaurimento de eventual discussão na esfera administrativa.

$\S 1^{\circ}$. As autoridades administrativas que tiverem conhecimento de quaisquer crimes ou indícios de suas práticas, especialmente os previstos nesta lei, sob pena de responsabilidade e independentemente de qualquer exaurimento de procedimento prévio de natureza administrativa, remeterão imediatamente ao Ministério Público os elementos comprobatórios ou indiciários da infração para a adoção das medidas legais cabíveis pelo titular da ação penal.

Da leitura deste dispositivo, fácil concluir a posição desta propositura no sentido de privilegiar a atuação do Ministério Público, e seu poder-dever de punir, sobre as garantias de ampla defesa e contraditório.

Assim, estaria defendendo a total independência das esferas administrativofiscal e penal, permitindo o encaminhamento de todo e qualquer material para o MP, antes de o contribuinte se defender plenamente na esfera administrativa.

Tal entendimento estaria em confronto com todas as teses até aqui levantadas e com o atual entendimento do STF acerca da matéria. Conforme demonstrado nesse trabalho, em nenhum momento foi retirado o direito do Ministério Público de deflagrar a ação penal: o que veio a se tornar cristalino em nosso ordenamento foi o aguardo do lançamento definitivo do tributo decisão final irrecorrível da esfera administrativa - para que houvesse o início do poder-dever de punir do MP.

Mesmo havendo alguns projetos de lei caminhando no sentido de mudar completamente o ordenamento jurídico como atualmente se apresenta, também há um projeto que vem consagrar o entendimento firmado por nossos Tribunais Superiores, bem como pela maioria da doutrina pátria. O Projeto de Lei 729/2007 prevê a seguinte implementação:

“Art. $2^{\circ}$. Fica acrescentado o $\S 2^{\circ}$ no art. 83 da Lei 9.430, de 27 de dezembro de 1996, com a seguinte redação: 
$\S 2^{\circ} \mathrm{O}$ julgamento administrativo tributário, em quaisquer de suas instâncias, é atividade essencial que integra o lançamento definitivo do crédito tributário, devendo a respectiva decisão administrativa ser devidamente fundamentada em seus aspectos de fato e de direito, sob pena de nulidade absoluta."

Diferentemente do que já foi trazido pelos demais projetos, o Projeto de Lei 729/2007 vem para consagrar o entendimento já estabelecido em nosso ordenamento.

Logo, nada mais justo do que acrescentar esse parágrafo $2^{\circ}$ ao dispositivo do artigo 83, pois após anos de discussão sobre esse assunto, essa foi a melhor solução encontrada para resolver a enorme e dogmática questão quanto à independência ou não das esferas. 


\section{5 - CONCLUSÃO}

Durante muitos anos perdurou o debate acerca da independência, ou não das esferas administrativo-fiscal e penal. Como exposto, cada corrente filiavase a um posicionamento diferente quanto à natureza jurídica do próprio lançamento para definir este conflito dogmático - condição de procedibilidade; questão prejudicial heterogênea; condição objetiva de punibilidade; e elemento normativo do tipo.

O Supremo Tribunal Federal, à luz da decisão do HC 81.611, criou entendimento no sentido de que, para os crimes contra a ordem tributária, quando os mesmos fossem de natureza material, não poderia ser iniciada a persecução penal, antes de exaurida a esfera administrativa - decisão final irrecorrível quanto ao lançamento definitivo do tributo. Nesse sentido, não importaria se a natureza jurídica do lançamento fosse condição objetiva de punibilidade, ou elementar do tipo.

Para resolver a questão da (in)dependência da esferas, entendemos que esta decisão estaria respaldada em pilares do nosso ordenamento jurídico, pois como foi demonstrado acabou por resolver a divergência quanto a direitos fundamentais colidentes, quais sejam, o direito de ampla defesa/contraditório $\mathrm{X}$ acesso a justiça/poder-dever punir.

À luz da proporcionalidade, ficou demonstrado no presente trabalho que este choque de princípios fundamentais acabou por resolver-se de maneira que prestigiasse ambos os lados, pois de acordo com a decisão do STF, o contribuinte poderia ter sua total ampla defesa na esfera administrativa, estando resguardado o poder-dever de punir do Estado, através do acesso a justiça pelo Ministério Público, para depois - caso o contribuinte não lograsse êxito na esfera administrativa. 
Ocorre que, com relação aos outros pontos, o entendimento consagrado pelo Excelso Pretório na decisão do leading case - HC 816.11 - bem como na edição da Súmula Vinculante nº 24 não encontrou uma solução viável.

Isso fica claro quanto à questão da prescrição, que está diretamente ligada à essência da natureza jurídica do lançamento definitivo - decisão final na esfera administrativa - pois, como demonstrado, se ficar plenamente entendido ser uma questão objetiva de punibilidade, não poderia se falar em suspensão da prescrição, pois o Supremo estaria legislando por conta própria, já que não há causa expressa de suspensão nesse sentido. E, caso ficasse entendido como elementar do tipo, também não haveria suspensão, pois, o crime não teria se consumado, tampouco teria se iniciado o curso da prescrição.

Pelos motivos aqui levantados, acompanhamos o entendimento que defende ser o lançamento definitivo, um elemento normativo do tipo, e, dessa maneira, não há que se cogitar em suspensão da prescrição, pois o crime não fora consumado.

Voltando esse tema ao plenário da Corte Maior, como sugerido, e seguindo nossa linha, o Verbete da Súmula Vinculante deveria estar acrescido do seguinte mandamento: “... não há que se cogitar em suspensão da prescrição, pois como elemento normativo do tipo, a mesma ainda nem se iniciou."

No que tange aos demais crimes que se assemelham àqueles prestigiados pela Súmula, os mesmos também deveriam constar do verbete supramencionado, pois, conforme apontado anteriormente, já é cristalina a posição de que os crimes previdenciários e de descaminho seguem a mesma estrutura dos crimes tributários.

Por outro turno, com referência as perspectivas de reforma legislativa, somos adeptos da linha que sustenta que a grande maioria dos Projetos de Lei em curso no Congresso não está em consonância com a atual ordem. Isto 
porque, foi demonstrado que a atual posição está ligada ao princípio da ofensividade, ou seja, as condutas tipificadas como crimes estão a zelar e proteger de maneira certa o bem juridicamente tutelado.

Em suma, não é através de uma reforma legislativa que traga mais severidade à legislação - com agravamento de penas, possibilidade de persecução penal antes mesmo do exaurimento da esfera administrativa e revogação dos benefícios concedidos ao devedor tributário - que será equacionado o grave problema da sonegação fiscal. Não se pode comprometer toda uma estrutura de um ordenamento jurídico complexo para satisfazer, conforme já enfatizado, uma obsessão do poder-dever de punir, quando, já ficou demonstrado, através de uma releitura da máxima da proporcionalidade, que essa não é a melhor maneira de se proceder.

Assim, com o presente estudo, acreditamos que, no exame do exaurimento da esfera administrativa para que se tenha início uma persecução penal, deverão prevalecer os princípios constitucionais da ampla defesa e do contraditório sobre a garantia de acesso à Justiça pelo Ministério Público no exercício de seu poder-dever de punir, uma vez que o bem jurídico que os primeiros buscam garantir - o direito de defesa do contribuinte - numa ponderação que leva em conta a proporcionalidade, se sobrepõe ao jus puniendi do Estado. 


\section{6 - BIBLIOGRAFIA}

ALEXY, Robert. Colisão de direitos fundamentais e a realização de direitos fundamentais no Estado de Direito Democrático. Revista de Direito Administrativo, Rio de Janeiro, n217, p. 67-79, jul./set. 1999.

ALEXY, Robert. Direitos fundamentais no Estado Constitucional Democrático: Para a relação entre direitos do homem, direitos fundamentais, democracia e jurisdição constitucional. Revista de Direito Administrativo, Rio de Janeiro, n. 217, p. 55-66, jul./set. 1999. Tradução de Luis Afonso Heck.

ALEXY, Robert. Direitos fundamentais, ponderação e racionalidade. Revista de Direito Privado, São Paulo, n. 24, p. 334-344, out./dez. 2005. Tradução de Luis Afonso Heck.

ALEXY, Robert. Teoria dos direitos fundamentais. Trad. da $5^{a}$ ed. alemã. São Paulo: Malheiros, 2008. 669p.

ANDREAS, Eisele. A representação fiscal e os crimes contra ordem tributária. Revista Dialética de Direito Tributário. São Paulo, n. 44, p.21-30, maio 1999.

AZEVEDO, David Teixeira de. A representação penal e os crimes tributários: reflexão sobre o artigo 83 da Lei 9430/96. Revista dos Tribunais, São Paulo, v.86, n 739, p. 475-486, maio de 1997.

BARANDIER, Antônio Carlos da Gama. Condição objetiva de punibilidade e crimes contra o sistema tributário. Boletim IBCCRIM. São Paulo, n. 57, p.13, ago. 1997.

COSTA, Claudio. Crimes de Sonegação Fiscal. Rio de Janeiro: Revan, 2003.128p. 
FERRARI, Eduardo Reale. A prejudicialidade e os crimes tributários. Boletim IBCCRIM, São Paulo, nº 50, p. 06, jan. 1997

FONTELES, Claudio. A constituição do crédito tributário não é condição objetiva de punibilidade aos delitos contra a ordem tributária. Revista dos Tribunais, v. 91, n796, p. 492-497, fev. 2002.

GAGLIARDI, Pedro Luiz Ricardo, A instância administrativa e os crimes tributários. In: COSTA, José de Faria; SILVA, Marco Antonio Marques da (Coord.). Direito penal especial, processo penal e direitos fundamentais: visão luso-brasileira. São Paulo: Quartier Latin, 2006, p. 535-553.

GOMES, Luiz Flavio. O prévio exaurimento da via administrativa nos crimes previdenciários ou tributários e a questão da suspensão do processo e da prescrição. In: BONATO, Gilson. Direito penal e direito processual penal: uma visão garantista. Rio de Janeiro: Lumen Juris, 2001, p. 151-163.

GOMES, Luiz Flávio. Princípio da ofensividade no direito penal: não há crime sem lesão ou perigo concreto de lesão ao bem jurídico (nullun crimen sine iniuria), funções político-criminal e dogmática-interpretativa, o princípio da ofensividade como limite do ius puniendi, o princípio da ofensividade como limite do ius poenale. São Paulo: Editora Revista dos Tribunais, 2002. 116p.

GOMES, Luiz Flávio. Reforma tributária e prévio exaurimento da via administrativa nos crimes tributários. Boletim IBCCRIM. São Paulo, v. 7, n. 86, p.3, jan. 2000.

GOMES, Luiz Flavio; BIANCHINI, Alice. Prévio exaurimento da via administrativa e crimes tributários. In: TANGERINO, Davi de Paiva Costa; GARCIA, Denise Nunes (Coords.). Direito Penal Tributário, São Paulo, Quartier Latin, 2007. p 83-126. 
KASAI, Jorge Eiji. Do procedimento administrativo e os crimes contra a ordem tributária e contra a previdência social. São Paulo: MP, 2008. 107p

MACHADO, Agapito. Nos crime fiscais/tributários a oferta da denúncia deve aguardar o término do procedimento administrativo fiscal? Revista Dialética de Direito tributário, São Paulo, nº 29, p. 7-9, fev. 1998.

MACHADO, Hugo de Brito. A Ação Penal nos Crimes contra a Ordem Tributária. Revista Dialética de Direito Tributário. São Paulo, n. 44, p.80-92, maio 1999.

MACHADO, Hugo de Brito. Crimes contra a ordem tributária. 2. ed.- São Paulo: Atlas, 2009. 420p.

MACHADO, Hugo de Brito. Prévio esgotamento da via administrativa e ação penal nos crimes contra a ordem tributária. Revista Brasileira de Ciências Criminais, São Paulo, nº 15, p. 231-239, jul/set 1996.

MACHADO, Pedro Antonio de Oliveira. \& FISCHER, Douglas. O inquérito policial ou a investigação criminal nos crimes contra a ordem tributária. Boletim dos Procuradores da República, ano IX, nº 74, p. 13-15, maio 2007.

MALAN, Diogo. Considerações sobre os crimes contra ordem tributária. Revista dos Tribunais, São Paulo, v. 96, n.865, p.450-481, novembro de 2007.

MARQUES, José Frederico. Tratado de Direito Penal, vol. 3, 2 ed. São Paulo: Saraiva, 1996.

MARTINS, Ives de Gandra da Silva. A procedibilidade a luz da lei 9.430/96. Revista Brasileira de Ciências Criminais, São Paulo, v. 6, n23, p 147-154, jul/set.1998.

MIRABETE, Julio Fabbrini. Processo Penal/ Julio Fabbrini Mirabete. - 13. Ed. rev. e atual. até dezembro de 2001 - São Paulo: Atlas, 2002. 760p. 
MORAES, Suzane de Farias Machado. Prévio esgotamento da via administrativa como condição para a ação penal nos crimes contra a ordem tributária. Revista Dialética de Direito Tributário. São Paulo, nº 97, p. 85-95, out. 2003.

PASCHOAL, Janaina Conceição; \& PASCHOAL, Jorge Coutinho. A constituição do crédito tributário: a consumação do crime tributário e a extinção da punibilidade pela prescrição. Boletim IBCCRIM, São Paulo, ano 16, n. 194, p. 2-3, jan. 2009.

PITOMBO, Sérgio Marcos de Moraes. Crimes contra a ordem tributária: sua persecução e a imaginada independência entre a administração e a jurisdição. Boletim do Instituto Manoel Pedro Pimentel. São Paulo, no 18, v 4, p. 18-20 Out.-Nov.-Dez/ 2001 .

PRADO, Luiz Regis. Apontamentos sobre a punibilidade e suas condicionantes positiva e negativa. Revista dos Tribunais, São Paulo, v. 89 , n.776,p. 440-452, jun. 2000.

ROSA JUNIOR, Luiz Emygdio F. da. Manual de direito tributário. Rio de Janeiro: Renovar, 2009. 834p.

SAAD, Marta \& MALAN, Diogo. Crimes contra a ordem tributária e a portaria SRF: Novo esforço para restaurar a lógica do sistema. Boletim do Instituto Brasileiro de Ciências Criminais, São Paulo, $\mathrm{n}^{\circ}$ 150, p. 11-12, maio de 2005.

SARMENTO, Daniel. Colisões entre direitos fundamentais e interesses públicos, In: SARMENTO, Daniel \& GALDINO, Flávio (Orgs.). Direitos Fundamentais: Estudos em homenagem ao professor Ricardo Lobo Torres, Rio de Janeiro: Renovar, 2006. p. 267-324. 
SCHOLZ, Leônidas Ribeiro. Crimes contra a ordem tributária e persecução penal. Revista dos Tribunais. São Paulo, v.86, n. 739, p.487-494, maio 1997.

SILVA, Aloísio Firmo Guimarães da. \& CORREA, Paulo Fernando. Considerações sobre a natureza jurídica da norma prevista no art. 83 da Lei 9430/96. Revista Brasileira de Ciências Criminais. São Paulo, v.6, $\mathrm{n}^{\circ} 23$, p.147-154, jul./set 1998.

SILVA, Gustavo Henrique de Souza e. A relação entre o processo administrativo de constituição de crédito tributário e os crimes de descaminho e de apropriação indébita previdenciária à luz da jurisprudência dos tribunais superiores. In: RESENDE, Sérgio Antonio de; PINTO, Felipe Martins; ESTEVES, Heloisa Monteiro de Moura (Org.). Análise de precedentes criminais do Superior Tribunal de Justiça: estudos em homenagem à Desembargadora Jane Ribeiro Silva. Belo Horizonte: Atualizar, 2009. p. 115131.

STF, ADIN 1.571-1/MC, Rel. Ministro Néri da Silveira, Brasília, 20 de mar. de 1997.

STF, ADIN 1.571-1, Rel. Ministro Gilmar Mendes, Brasília, 10 de dez. de 2003

STF, ADIN 2.797-2, Rel. Ministro Sepúlveda Pertence, Brasília, 15 set. de 2005.

STF, HC 75.723, Rel. Ministro Carlos Velloso, Brasília, 18 nov. de 1997.

STF, HC 81.611-8, Rel. Ministro Sepúlveda Pertence, Brasília, 10 dez. de 2003.

STF, HC 85.428-1, Rel. Ministro Gilmar Mendes, Brasília, 17 mai. de 2005. 
STF, HC 86.120-2, Rel. Ministro Sepúlveda Pertence, Brasília, 09 ago. de 2005.

STF, HC 83.353-5, Rel. Ministro Marco Aurélio, Brasília, 13 set. de 2005.

STF, HC 85.463-0, Rel. Ministro Carlos Britto, Brasília, 07 jun. de 2005.

STF, HC 85.185-1, Rel. Ministro Cezar Peluso, Brasília, 10 de ago. de 2005.

STF, INQ 2537/Agr, Rel. Ministro Marco Aurélio, Brasília, 10 mar. de 2008.

STJ, AgHC 109.488, Rel. Ministra Jane Silva, Brasília, 13 out. de 2008.

STJ, HC 109.205, Rel. Ministra Jane Silva, Brasília, 02 de out. de 2008.

STJ, RHC 6898, Rel. Ministro Vicente Leal, Brasília, 27 out. de 1997.

STJ, RESP 59512, Rel. Ministro Jesus Costa Lima, Brasília, 26, abr. de 1995.

TORON, Alberto Zacharias; \& TORIHARA, Edson Junji. Crimes tributários e condição de procedibilidade. Boletim IBCCRIM. São Paulo, $\mathrm{n}^{\circ}$ 51, p.8, fev.1997.

TUCCI, Rogério Lauria. Breve estudo sobre a ação penal relativa a crimes contra a ordem tributária. Revista do Advogado, São Paulo, n. 53, p7-17, out. 1998.

TUDISCO, Flávio. Controvérsias sobre o direito penal tributário. Valor Econômico. São Paulo, p. E04. 21 mai 2010.

VELASQUES, Renato Vinhas \& HOFFMANN, Magali Mannhart. Artigo 83 da Lei 9430/96 e a ação penal nos crimes contra a ordem tributária. Revista dos Tribunais, São Paulo, v. 86, n 745, p. 459-462, Nov. 1997. 
VIDGAL, Edson Carvalho. Fluxo de Cadeia ou de caixa - O exaurimento da instância administrativo-fiscal como condição de procedibilidade para a ação penal. Revista dos Tribunais, n764, p. 453-458, jun 1999.

WIGGERS, Gustavo \& BISSOLI FILHO, Francisco. A inconstitucionalidade do encerramento do processo administrativo fiscal como condição de procedibilidade para o exercício da ação penal. Boletim IBCCRIM, São Paulo, v.8, n.93, p. 13-15, ago. 2000. 